\title{
The interplay between short-term, mild physicochemical forcing and plankton dynamics in a coastal area
}

\author{
Estela Romero, ${ }^{*}$ Francesc Peters, and Òscar Guadayol ${ }^{1}$
}

Institut de Ciències del Mar, Consejo Superior de Investigaciones Científicas (CSIC), Barcelona, Catalunya, Spain

\begin{abstract}
Two intensive surveys were conducted in the coastal waters of Barcelona (northwest Mediterranean) to assess short-term variations of biological parameters in relation to environmental conditions. Surveys lasted 1 week, with three to four samplings per day, and were carried out in autumn and spring. Rather than exploring extreme events, we aimed to study the effects of regular low or moderate perturbations, such as meteorological fronts, on the dynamics of the system. We focused on two attributes: wave height, as a proxy for mechanical energy entering the system, and nutrient inputs, whose variability in total load and relative composition is a central characteristic of coastal areas. The effects of the temporal coupling or uncoupling of both factors were examined. Sudden nutrient fluxes uncoupled from water motion tended to favor bacteria and heterotrophic nanoflagellates, while their concurrence with some water column mixing shaped a favorable scenario for large autotrophs. Ultimately, these two distinct biological responses pointed toward two main disturbance scenarios: episodes of nutrient enrichment uncoupled from mixing, mostly related to episodic water spills from the nearby city that contributed to high relative loads of ammonium and organic compounds; and episodes of increased wind caused by passing weather fronts that promoted some water column mixing and the entrainment of nutrients from bottom sediments or from adjacent water masses.
\end{abstract}

Time series of monthly samplings have proved very useful to assess the importance of intrinsic and humaninduced coastal variability vs. the characteristic seasonality of open-sea waters (Cloern and Jassby 2008). Moreover, multiyear time series of monthly measurements are a valuable tool to study the response of the community to severe episodic disruptions, such as rough seas or large river freshets. Plankton day-to-day variability, however, is also modulated by less intense physical perturbations. Tides are one of the major drivers of short timescale dynamics in coastal areas. Tides induce shifts in the direction and speed of currents, which in turn affect water column mixing, turbidity, and planktonic populations (Cloern 1991; Franks and Chen 1996; Porter et al. 2010).

In the northwest Mediterranean, tides are very weak (maximum tidal amplitudes barely exceed $\sim 25 \mathrm{~cm}$ ) and their effect is overshadowed by the wide set of disturbances present in urbanized nearshore environments. In the absence of strong tides, weather fronts are one of the recurrent perturbations that most affect coastal dynamics. Fronts entail shifts in atmospheric pressure and dominant winds, and their passage is often related to overall increased instability. Here we do not consider occasional heavy fronts that feature thunderstorms and intense rainfall, and we refer to mild weather fronts as those recurrent meteorological phenomena (one passage approximately every 4-8 d) that entail low or moderate changes in wind speed and wave height (in no case exceeding the range [mean \pm 2 standard deviations] of a climatological time series for the

\footnotetext{
* Corresponding author: estela@icm.csic.es
}

\footnotetext{
${ }^{1}$ Present address: Hawai'i Institute of Marine Biology, School of Ocean and Earth Science and Technology, University of Hawai'i at Mānoa, Kāne'ohe, Hawai'i
}

same region). Related turbulence and mixing processes influence water temperature, salinity, and the concentration of organic and inorganic compounds, which can be resuspended from the bottom sediment. The closeness to land favors additional nutrient inflows due, for instance, to runoff that can be uncoupled from turbulent motion.

Hence, both turbulence and nutrient concentrations at coastal sites can change on a timescale of hours to days, and they may induce transient variations in growth, fluctuations in biomass, or alter competition among planktonic species. Previous field and laboratory studies have shown that intermittent nutrient supply can dramatically change phytoplankton community composition (Roelke et al. 1999; Spatharis et al. 2007), that shifts in mixing regimes can lead to changes in competition between fast- and slow-sinking species (Kiørboe 1993; Pinckney et al. 1999), and that light attenuation caused by inputs of suspended matter can affect planktonic growth and community structure (Alpine and Cloern 1988; Grémare et al. 2003). Nonetheless, the combined effect of these factors on the dynamics of the whole community is still poorly understood, particularly if we disregard extreme events and consider only the most frequent episodes, in which the intensity of the forcing is moderate to low.

Pannard et al. (2008b) underlined the importance of short timescales for the understanding of the functioning of coastal systems and the grievous lack of this type of studies in the field. Although phytoplankton dynamics in laboratory experiments is mainly studied at short timescales, in situ dynamics of natural communities is generally explored using lower sampling frequencies. Experiments are often conceived to mimic extreme conditions and set up maximum response thresholds, so that specific experimental results are not easy to extrapolate to natural systems. 
Finally, the response of the organisms to environmental perturbations has been shown to depend on the initial composition and structure of the planktonic community (Estrada et al. 1987; Guadayol et al. 2009a). As a result, seasonal variations in the dominant groups may influence the response to short-term physical forcing. Seasonality is also an important issue to consider with regard to the characteristics of environmental phenomena. Meteorologically, spring and autumn are the most variable seasons in the northwest Mediterranean. Thus, these seasons are interesting periods to assess the links between physicochemical and biological variables.

In the present study, short-term variations of biological parameters were studied with regard to changes in the environmental conditions. We focused on two attributes: wave height, as a proxy for mechanical energy entering the system, and nutrient inputs. Rather than exploring singular extreme events, we aimed to assess the effects of ordinary low or moderate perturbations, such as weather fronts, on the dynamics of the system. We test whether recurrent, short-term disturbances can induce biological shifts comparable to seasonal changes. We hypothesize that the temporal coupling or uncoupling of nutrients and water column mixing is central for the balance between large autotrophs and small-sized organisms that make up a very tight microbial loop.

\section{Methods}

Study area -We conducted two surveys in Barcelona's littoral $\left(41^{\circ} 22.914^{\prime} \mathrm{N}, 2^{\circ} 11.970^{\prime} \mathrm{E}\right)$, on the northwest Mediterranean coast. The sampling station is located close to the city of Barcelona, in a shallow site (about $10 \mathrm{~m}$ depth) featuring a soft, sandy bottom. The main current in the study area is the southwestwards littoral drift, a derivative of the Liguro-Provençal Current that is the prevailing oceanographic current in the Catalan margin (Font et al. 1988). The main oceanographic, geological, and hydrographical features of Barcelona's continental shelf are extensively reviewed in Liquete et al. (2007).

The city exerts a continuous pressure on the adjacent marine system. Major disturbances are linked to human activities such as the construction works of ports and harbors, widespread recreational sailing, anchor dragging, or dredging for beach nourishment. In addition, the study area is located between the mouths of two large rivers, the Besòs River to the north and the Llobregat River to the south (Fig. 1), whose catchment basins comprise industrialized areas and house $>4.6$ million inhabitants (ACA 2005). Additionally, two storm sewer overflows are placed at a close distance from our sampling site (Fig. 1). Storm overflows are used to release freshwater during intense storms, when runoff exceeds the capacity of the city's sewer system. They thus represent an intermittent, yet heavy disruption into nearshore waters. Despite all these factors, nutrient and chlorophyll (Chl) concentrations in the area are generally low and the region has not shown, so far, severe signs of eutrophication (on average, $0.19 \pm 0.06 \mu \mathrm{mol}$ $\mathrm{PO}_{4}^{3-} \mathrm{L}^{-1}, 1.04 \pm 0.79 \mu \mathrm{mol} \mathrm{NO}{ }_{3}^{-} \mathrm{L}^{-1}, 0.93 \pm 0.39 \mu \mathrm{mol}$ $\mathrm{H}_{4} \mathrm{SiO}_{4} \mathrm{~L}^{-1}$, and $1.58 \pm 1.09 \mu \mathrm{g} \mathrm{Chl} \mathrm{L}{ }^{-1}$ for the 2002-2008 period, according to data for the same station from the Institut de Ciències del Mar Coastal Ocean Observatory; http://coo.icm.csic.es/content/barcelonasol).

Sampling scheme-We carried out two intensive surveys: the first one took place in autumn (November 2005) and the second one was conducted in spring (April 2006). Each survey lasted 1 week, with three to four samplings per day (one every $3 \mathrm{~h}$, starting at 09:00 h). There is, on average, one meteorological front every 4 to $8 \mathrm{~d}$ in this part of the Mediterranean, so we expected that 1 week surveys would catch, at least, the passage of one front. In brief, subsurface waters $(3 \mathrm{~m}$ depth) were sampled by means of a Niskin bottle and immediately transferred to 2.5 liter polycarbonate carboys. The carboys had been acid-washed and thoroughly rinsed with Milli-Q water and sample water, and were transported to the laboratory under dim light within $15 \mathrm{~min}$. We only sampled at one depth because these are shallow waters that tend to be well mixed throughout the year; this was confirmed by a $7 \mathrm{yr}$ series of monthly samplings carried out in the same station where surface and bottom samples were analyzed (surface and bottom waters showed similar temporal patterns and the divergence was $10 \%$ on average for all nutrients, and about $5 \%$ for $\mathrm{Chl} a$ ). Additionally, conductivity-temperature-depth (CTD) vertical profiles were obtained at the station and at two more stations located nearby (Fig. 1). The CTD probe was a SeaBird Electronics SBE 25 CTD SN97. CTD raw data were processed through the SBE data processing software (SEASOFT - Win32) to obtain the hydrographic parameters of the water column. Fluorescence measurements were carried out by specific sensors coupled to the CTD (Sea Tech Fluorometer in November 2005, and Seapoint Chlorophyll Fluorometer in April 2006).

Hydrological and meteorological data-Meteorological data were kindly provided by the Spanish Meteorological Agency (www.aemet.es). Data came from a meteorological station located at the seafront $\left(41^{\circ} 23.45^{\prime} \mathrm{N}, 2^{\circ} 12.08^{\prime} \mathrm{E} ; 21 \mathrm{~m}\right.$ height), close to our sampling site (meteorological Sta. 1 [Meteo. Sta. 1] in Fig. 1). They supplied hourly accumulated rainfall and hourly averaged data for air temperature, wind speed, and wind direction. Wind parameters consisted of vector averages and were measured at $10 \mathrm{~m}$ above the ground. We used a supplementary set of parameters from the Catalan Meteorological Service (www.meteo.cat). Data were retrieved from an automated station located in the outskirts of the city $\left(41^{\circ} 25.104^{\prime} \mathrm{N}, 2^{\circ} 7.434^{\prime} \mathrm{E}\right.$; $411 \mathrm{~m}$ height [Meteo. Sta. 2 in Fig. 1]), and comprised hourly averages for air pressure, irradiance, and relative humidity.

Oceanographic parameters (wave height, water temperature) came from a directional wave buoy deployed southwards of our sampling station $\left(41^{\circ} 19.3^{\prime} \mathrm{N}, 2^{\circ} 12.4^{\prime} \mathrm{E}\right.$; Fig. 1) over a depth of $68.5 \mathrm{~m}$ (Red Costera de Boyas de Oleaje, REDCOS network, Puertos del Estado). Data from a second buoy placed near the Llobregat River mouth $\left(41^{\circ} 16.69^{\prime} \mathrm{N}, 02^{\circ} 08.48^{\prime} \mathrm{E} ; 45 \mathrm{~m}\right.$ depth [Xarxa d'Instruments Oceanogràfics i Meteorològics, XIOM network, Generalitat de Catalunya]) were used to fill occasional gaps in the time series, applying a simple linear model that accounted 


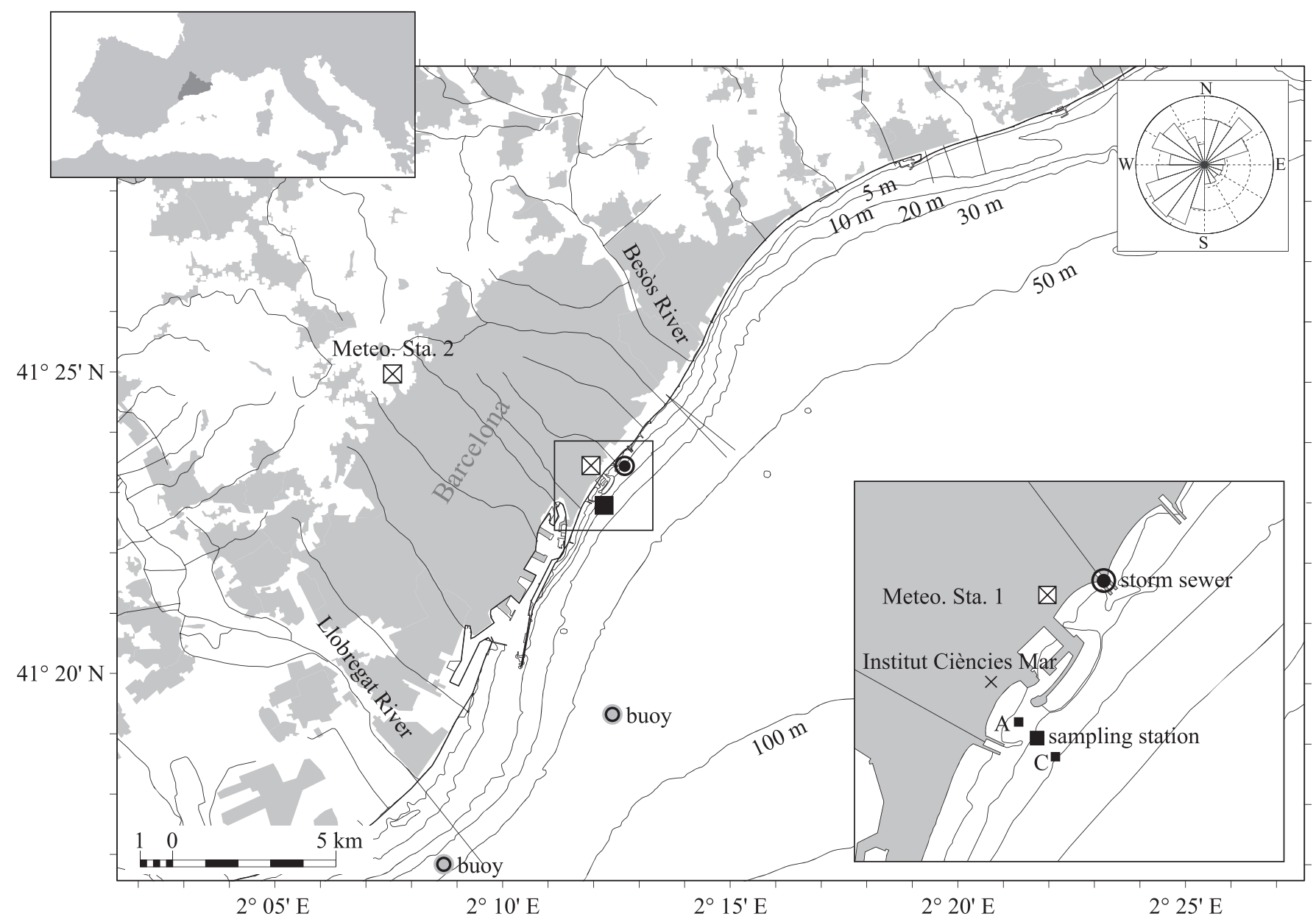

Fig. 1. Study area. The city of Barcelona is located between the mouths of the Besòs River (north) and the Llobregat River (south). (A, C) Our sampling station and the two complementary stations where CTD profiles were obtained are marked with black squares. Gray areas indicate urbanized land; white squares with crossed lines stand for meteorological (Meteo.) stations, gray circles represent wave buoys. A wind rose showing the dominant winds in the study area is included in the top right corner. The inset map shows a zoom of the sampling site, with the sewer overflows located north and south of the sampling station. Outflow data were obtained for one of these sewer overflows (tagged with a black circle). Long straight lines near the coastline represent marine outfalls.

for $>96 \%$ of the variance. Both buoys provided hourly averaged data.

Storm sewer outflow data were supplied by Clavegueram de Barcelona. Barcelona's sewer system has a number of underground rainwater tanks to collect rainfall and terrestrial runoff for flood prevention and routine city drainage. When large downpours occur that exceed the capacity of the system, part of the water is released to the sea through these coastal drainage pipes. We obtained data from their Sta. L20 $\left(41^{\circ} 23.516^{\prime} \mathrm{N}, 2^{\circ} 12.160^{\prime} \mathrm{E}\right.$; Fig. 1), north of our sampling site.

Biological and chemical water column parameters-Inorganic nutrient concentrations were determined spectrophotometrically with an Alliance Evolution II autoanalyzer following standard procedures (Hansen and Koroleff 1999). Samples were kept frozen at $-20^{\circ} \mathrm{C}$ until analysis.

Particulate organic carbon (POC) and nitrogen (PON) were collected on pre-combusted Whatman GF/F filters (up to $1000 \mathrm{~mL}$ ). Samples were immediately frozen in liquid nitrogen and stored at $-80^{\circ} \mathrm{C}$ until analysis. Measurements were performed with a Perkin Elmer 2400 carbonhydrogen-nitrogen analyzer (Álvarez-Salgado et al. 2001). An acetanilide standard was used daily. The precision of the method is $\pm 0.3 \mu \mathrm{mol} \mathrm{C} \mathrm{L}{ }^{-1}$ and $\pm 0.1 \mu \mathrm{mol} \mathrm{N} \mathrm{L}^{-1}$.

Total phosphorus (TP) was determined by wet oxidation and colorimetry (Hansen and Koroleff 1999). In short, $25 \mathrm{~mL}$ aliquots were mixed with $2 \mathrm{~mL}$ of the oxidant reagent in glass vials, and autoclaved at $121^{\circ} \mathrm{C}$ for $30 \mathrm{~min}$. The vials were cooled down to room temperature, then $600 \mu \mathrm{L}$ of ascorbic acid was added and left to act for $2 \mathrm{~min}$. Finally, we pipetted $600 \mu \mathrm{L}$ of the combined reagent into each vial and kept samples in the dark for $15 \mathrm{~min}$. Readings were done at $880 \mathrm{~nm}$ with a Cary Win Ultraviolet Spectrophotometer.

Total organic carbon (TOC) and total nitrogen (TN) were measured with a Shimadzu TOC- $\mathrm{V}_{\mathrm{CSH}}$ analyzer equipped with the additional TN module, as described in Nieto-Cid et al. (2005). Samples of $\sim 10 \mathrm{~mL}$ of water were collected in pre-combusted $\left(450^{\circ} \mathrm{C}, 12 \mathrm{~h}\right)$ glass ampoules 
and immediately acidified to $\mathrm{pH}<2$ by adding $\mathrm{H}_{3} \mathrm{PO}_{4}$. The ampoules were heat-sealed and stored in the dark at $4{ }^{\circ} \mathrm{C}$ until analysis. We used a catalytically aided platinum $680^{\circ} \mathrm{C}$ combustion technique. The system was standardized daily with a potassium hydrogen phthalate standard. The accuracy of the analyzer was tested with the reference dissolved organic materials provided by D. Hansell (University of Miami). Detection limits for carbon and nitrogen were $4 \mu \mathrm{g} \mathrm{C} \mathrm{L}^{-1}$ and $5 \mu \mathrm{g} \mathrm{N} \mathrm{L}^{-1}$, respectively.

Total chlorophyll $a$ and chlorophyll $>10 \mu \mathrm{m}$ were determined fluorometrically following the methods in Yentsch and Menzel (1963). For total chlorophyll $a$, we filtered 20-40 mL samples through Whatman GF/F glassfiber filters; for the $>10 \mu \mathrm{m}$ fraction, 30 to $50 \mathrm{~mL}$ samples were filtered through $10 \mu \mathrm{m}$ pore-size Whatman Nuclepore polycarbonate filters. Filters were immersed in acetone $(90 \% \mathrm{v}: \mathrm{v})$ and left in the dark $\left(4^{\circ} \mathrm{C}, 24 \mathrm{~h}\right)$ to allow for pigment extraction. The fluorescence of the extract was measured with a Turner Designs fluorometer. All samples were done in duplicate.

Abundances of bacteria and autotrophic picoplankton (Prochlorococcus sp., Synechococcus sp., and eukaryotic picoplankton) were determined by flow cytometry (Gasol and del Giorgio 2000). Samples (1.8 mL) were preserved with $1 \%$ paraformaldehyde and $0.05 \%$ glutaraldehyde (final concentration), deep frozen in liquid nitrogen, and stored frozen at $-80^{\circ} \mathrm{C}$. For bacteria, subsamples of $200 \mu \mathrm{L}$ were stained with SYTO13 (Molecular Probes) at $2.5 \mu \mathrm{mol} \mathrm{L}{ }^{-1}$ (diluted in dimethyl sulfoxide), left for 15 min to stain in the dark, and then ran at low speed $\left(\sim 12 \mu \mathrm{L} \mathrm{min}{ }^{-1}\right)$ through a flow cytometer. We used a bench fluorescence-activated cell sorter FACScalibur (Becton and Dickinson) with a laser emitting at $488 \mathrm{~nm}$. As an internal standard, we added $10 \mu \mathrm{L}$ per sample of a $10^{6} \mathrm{~mL}^{-1}$ solution of yellow-green $0.92 \mu \mathrm{m}$ latex beads (Polysciences). Bacteria were detected by their signature in a plot of side scatter vs. green fluorescence. For picophytoplankton, subsamples of $600 \mu \mathrm{L}$ were left unstained and ran at high speed $\left(\sim 60 \mu \mathrm{L} \mathrm{min}{ }^{-1}\right)$. A volume of $10 \mu \mathrm{L}$ of a $10^{6} \mathrm{~mL}^{-1}$ solution of latex beads was used as an internal standard. Cyanobacteria and picoeukaryotes were discriminated in a plot of green vs. red fluorescence. As a cross control to determine the concentration of cells and to ensure the stability of the flow, the flow speed was calibrated every 10 samples by measuring sample volume before and after a 10 min run.

Autotrophic and heterotrophic nanoflagellates were enumerated by epifluorescence microscopy (Porter and Feig 1980). Samples were fixed with glutaraldehyde (1\% final concentration), stained with 4',6-diamidino-2-phenylindole (DAPI, $5 \mu \mathrm{g} \mathrm{mL}^{-1}$ ), and filtered on $0.8 \mu \mathrm{m}$ black polycarbonate membranes. The filters were subsequently mounted on microscope slides and kept frozen at $-20^{\circ} \mathrm{C}$ until enumeration. A Nikon Labophot epifluorescence microscope at $\times 1250$ magnification was used for the counting. Approximately 180 to 200 organisms were counted on each filter. We measured the size of the cells using a calibrated ocular micrometer and sorted the organisms into four categories $(<4 \mu \mathrm{m}, 4-8 \mu \mathrm{m}, 8-16 \mu \mathrm{m}$, $>16 \mu \mathrm{m})$. Size classes are required to further estimate cell biovolumes and corresponding $\mathrm{C}$ biomass. Autotrophic and heterotrophic nanoflagellates were distinguished by the red fluorescence of chlorophyll under blue light.

Samples for microphytoplankton were fixed with a formalin-hexamine solution ( $0.4 \%$ final concentration) and kept at $4{ }^{\circ} \mathrm{C}$ until analysis. Organisms (size range 20 $200 \mu \mathrm{m}$ ) were identified and counted in $50 \mathrm{~cm}^{3}$ settling chambers using an inverted microscope at $\times 100$ and $\times 400$ magnifications (Utermöhl 1958). The dominant taxonomic groups (diatoms, dinoflagellates, coccolithophores, ciliates) were sized (length and width) and classified to the lowest possible taxonomic level.

Plankton biomass - Chlorophyll $a$ values were converted to carbon using a factor of $50 \mu \mathrm{g} \mathrm{C} \mu \mathrm{g} \mathrm{Chl}^{-1}$. Delgado et al. (1992) reported similar estimates for chlorophyll biomass in surface waters of the northwest Mediterranean. Bacterial biomass was obtained by flow cytometry following the methods in Gasol and del Giorgio (2000); we used a carbon

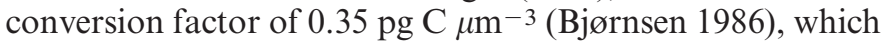
resulted in an average value of $21 \mathrm{fg} \mathrm{C}$ cell ${ }^{-1}$. Cell volume of nanoflagellates was established from the mean value of each size category, assuming a prolate spheroid shape. Conversion to carbon was derived from the equation by Verity et al. (1992): pg C cell ${ }^{-1}=0.433 \times\left(\mu \mathrm{m}^{3}\right)^{0.863}$.

Statistics-Pearson $r$-coefficients are given for correlation analyses between variables. Due to its robustness with large data sets, Pearson $r$ was also used for parameters that presented slight deviations from normality provided that the sample size was large enough. For those variables with a low number of samples $(n<25)$, nonparametric correlation analyses were performed and Spearman rho coefficients are given instead. Analysis of similarity was used to test for differences in the composition between the autumn and spring initial communities. Principal components analyses (PCA) were performed on the physicochemical factors to visualize the grouping of environmental variables, and on the log-transformed concentration of organisms to determine shifts in the community (Jolliffe 1986). Further, to detect delays in the response of the organisms with regard to the physical forcing, we performed cross correlations. A cross correlation is a mathematical method to estimate the covariation of two time series as a function of the time lag between them. Albeit this analysis usually requires data sets with the same sampling frequency, the method has been successfully used to examine data collected at different intervals (Guadayol et al. 2009b). Owing to the lack of biological and chemical data at night, cross correlograms showed slightly serrated peaks; we smoothed these notches by linearly interpolating a few points at night hours, and checked that interpolated data did not affect the outcome of cross correlations. All statistical analyses were done with Statistica version 6 (StatSoft), PAST version 2.16 (Hammer et al. 2001), and JMP version 8 (SAS Institute). CTD profiles were plotted with Ocean Data View (ODV v.3.4.3, AWI).

\section{Results}

Autumn survey-Background conditions: Wind speed ranged from $2 \mathrm{~m} \mathrm{~s}^{-1}$ to nearly $14 \mathrm{~m} \mathrm{~s}^{-1}$ (Fig. 2), and 

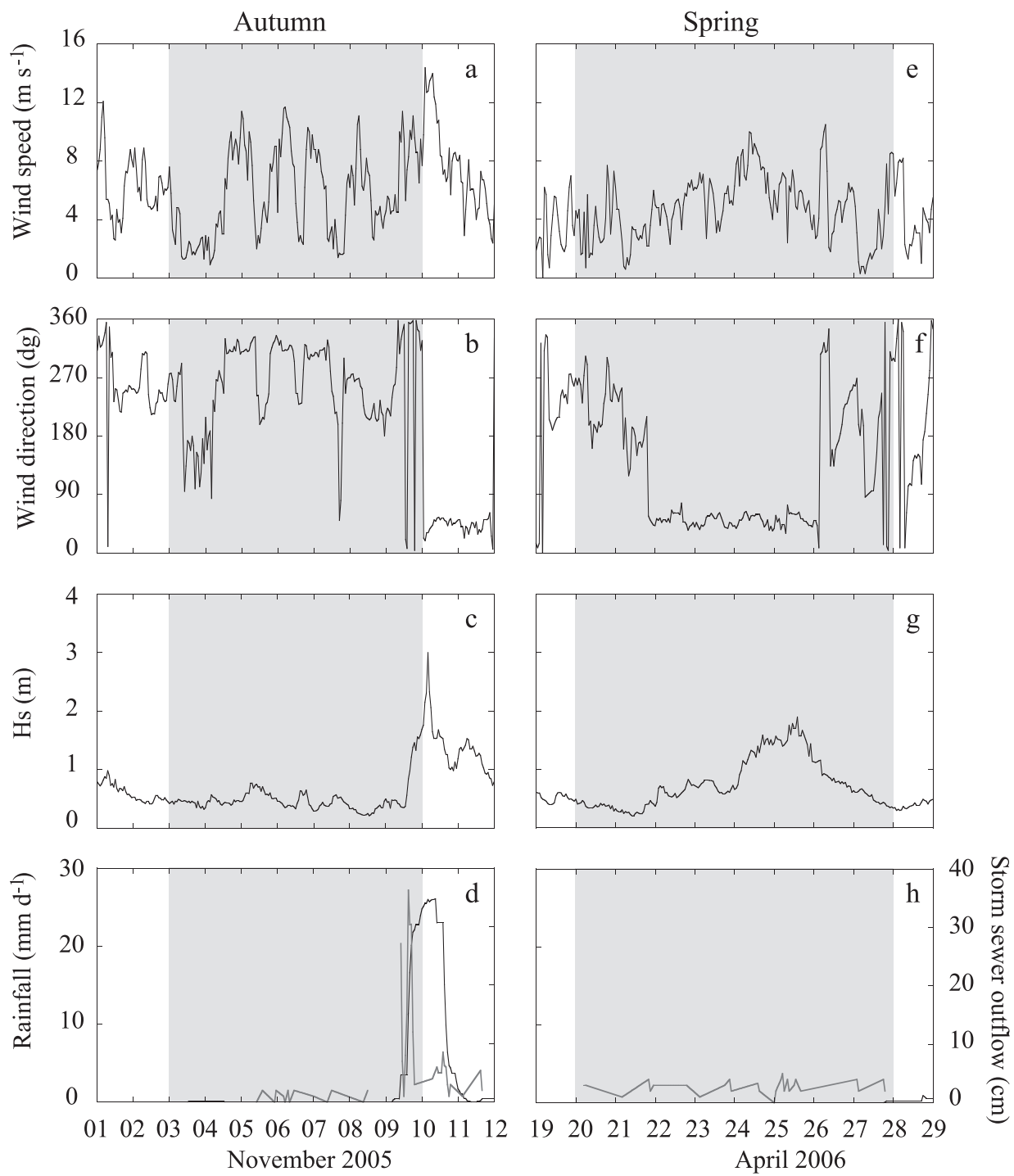

Fig. 2. (a-h) Wind speed, wind direction, wave height, and rainfall during the autumn (left) and spring (right) surveys. Rainfall refers to daily accumulated rainfall (black line), whereas sewer outflows are measured as increases in the height of the water layer (gray line). (d, h) Storm sewer outflow is considered nonexistent unless the height of the water layer exceeds $10 \mathrm{~cm}$. The shaded area indicates the sampling period.

maximum wind speed values were registered towards the end of the sampling survey (09-10 November), coinciding with the arrival of a strong cold front (Catalan Meteorological Service monthly bulletins). Winds showed a regular daily pattern during the central days of the survey (05-08 November), with lower velocities around midday $(\sim$ 10:00 $\mathrm{h}$ to $17: 00 \mathrm{~h}$ ) and higher values at night, which also matched with a periodicity in wind direction: prevailing northwest winds shifted to south-southwest from around midday until the afternoon (Fig. 2). This pattern corresponds to the typical daily breeze regime (locally known as "marinades"; Martínez Albaladejo 1996). Regular breezes vanished on 09 November, and wind direction changed abruptly to sustained east winds from 10 November, when the cold front fully reached the study area. The passage of the cold front entailed higher wind velocities, increased turbulence in the water (significant wave height [hereafter, $\mathrm{H}_{\mathrm{s}}$ ] reached maximum values), and some precipitation. Shortly after the rainfall began, there were freshwater spills from the two storm sewer overflows located close to the sampling station (Fig. 2). The drop in salinity could be observed in the CTD profiles (Fig. 3). Air temperature ranged from $11^{\circ} \mathrm{C}$ to $20^{\circ} \mathrm{C}$, and water temperature decreased steadily, $\sim 1^{\circ} \mathrm{C}$ throughout the week $\left(19^{\circ} \mathrm{C}\right.$ to $18^{\circ} \mathrm{C}$ ). Although the highest waves were coupled with the arrival of frontal east winds, there was a moderate local peak in $\mathrm{H}_{\mathrm{s}}$ on 05 November.

Nutrient availability: Shifts in nutrient concentrations seemed to be somewhat delayed with regard to meteorological phenomena (Fig. 4). The concentration of nutrients was low during the first $3 \mathrm{~d}$ of the survey (except for silicate 
a) Autumn
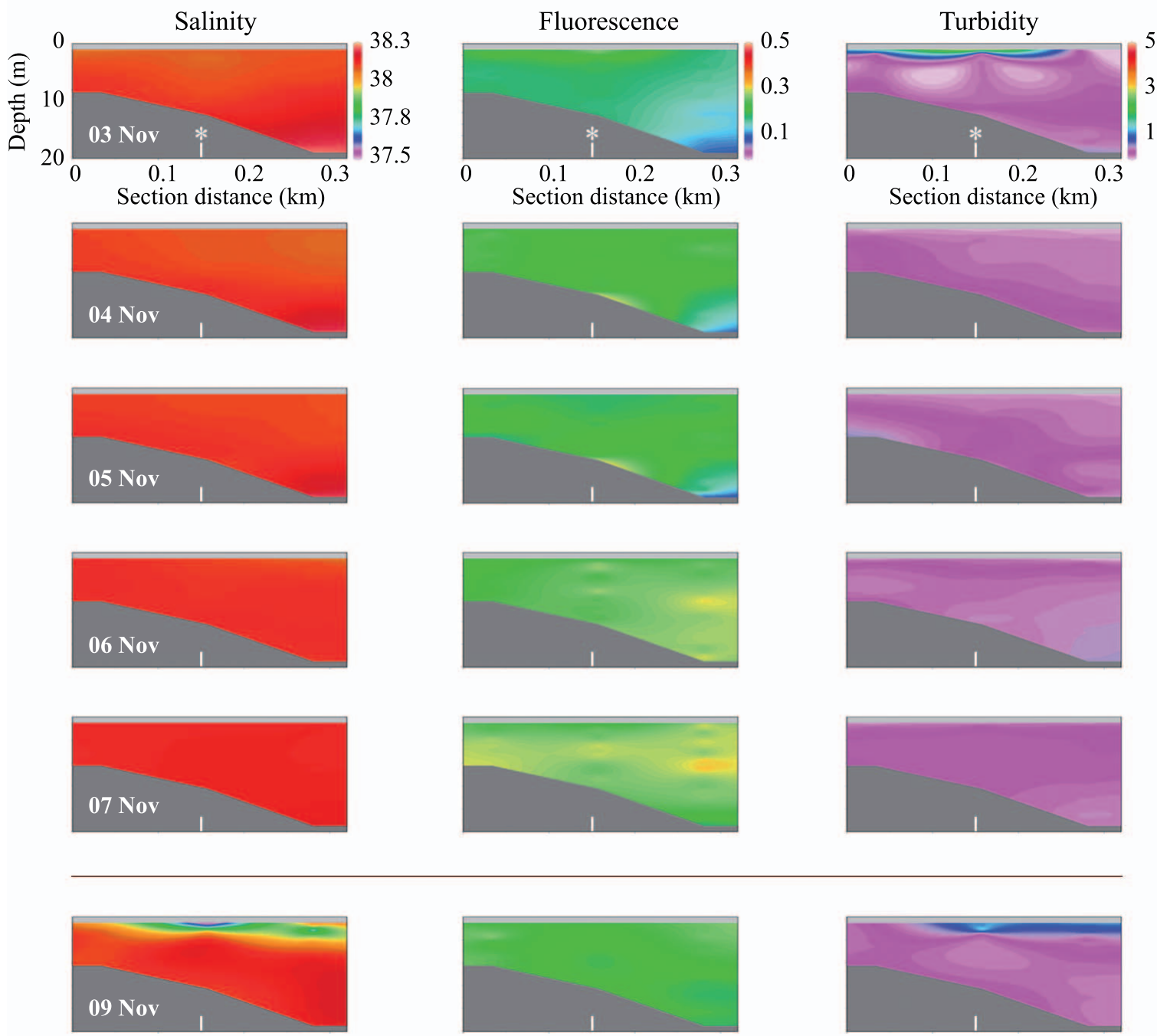

Fig. 3. CTD profiles for salinity, fluorescence, and turbidity along a cross section, including the sampling station (white line with asterisk) and two other sampling sites located onshore (Sta. A in Fig. 1) and offshore (Sta. C in Fig. 1). Data were spatially interpolated using the data-interpolating variational analysis (DIVA) gridding method. (a) Autumn and (b) spring; top to bottom, every row represents $1 \mathrm{~d}$. Note that we did not have any profile on 08 November, nor on 26 April.

and ammonium) and a general increase occurred between 05 and 06 November, particularly evident for nitrate (Fig. 4). The shift in nutrient dynamics was hence observed $1 \mathrm{~d}$ after the onset of stable breezes. Nutrients remained sufficient for growth until the last day except for nitrate, which dropped off right after the inflow of rainwaters. Variations in the concentration of nutrients led to changes in the associated ratios: $\mathrm{N}: \mathrm{P}$ values swung initially around 16 but decreased over the following days; the quotient $\mathrm{NH}_{4}^{+}: \mathrm{NO}_{3}^{-}$was on average 5 during the first $3 \mathrm{~d}$, decreased to 1.64 after 06 November, and increased again $(\sim 7.7)$ following freshwater inputs. TOC and TN showed little variability throughout the survey, but a clear increase of TP occurred on 05 November (not shown). The mismatch between $\mathrm{TN}$ and inorganic $\mathrm{N}$ compounds suggests that an important part of the $\mathrm{N}$ pool was in the form of organic substances, as it has been also shown for the nearby area of Blanes (Lucea et al. 2005). In contrast, most phosphorus was in the form of inorganic phosphate (on average, $\mathrm{PO}_{4}^{3-}: \mathrm{TP} \sim 0.6 \pm 0.2$ ).

PCA (Fig. 5a) results showed a complex suite of factors acting together, consistent with the fact that no obvious single perturbation occurred during the sampling week. The first component (C1) explained $34 \%$ of the variance and the second (C2) accounted for $28 \%$. C1 was positively correlated to inorganic nitrogen, phosphorus, particulate matter, and wind speed, and negatively to silicate and organic carbon. C2 was positively correlated to nutrients and salinity, and negatively linked to wave height and rainfall. $H_{s}$ was somewhat closer to rainfall than to wind speed during the autumn survey, likely because the large wave peak at the end of the survey affected the correlations. Largely, nutrients (except for silicate), salinity, and wind speed clustered together in the first 
b) Spring
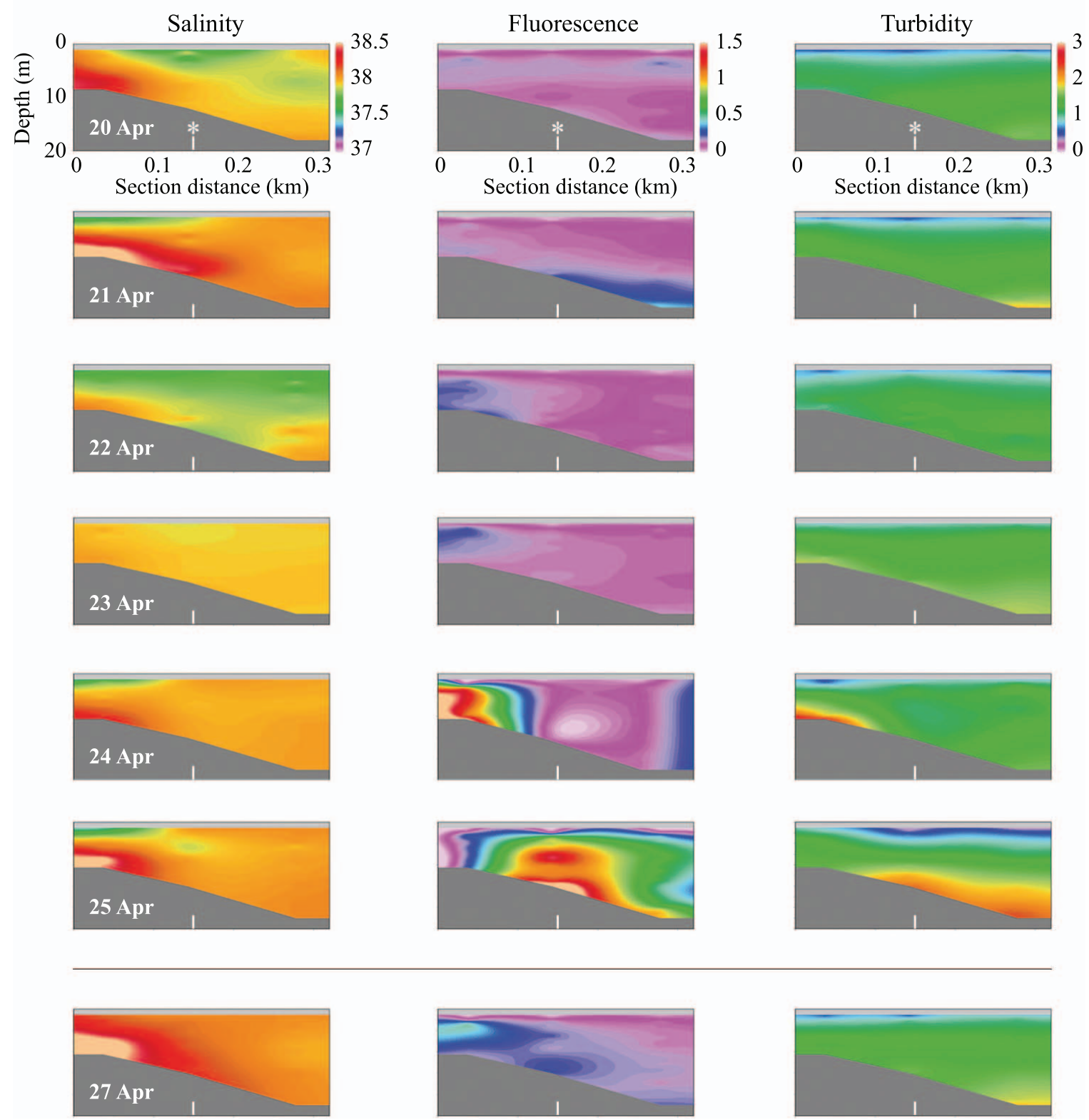

Fig. 3. Continued.

component, whereas organic carbon and silicate were dissociated. Wave height, rainfall, and lower values for salinity and nitrate determined an alternate situation.

Plotting the scores (eigenvalues) of each sampling on this vector space (C1 vs. C2, Fig. 5c), we can distinguish three different periods (Table 1), also recognizable in the raw data: (1) the first days, featuring low winds, moderate waves, low nutrients, and higher values of total organic carbon; (2) a central period (06-08 November) displaying marked daily breezes, slightly higher salinity, higher nutrient concentrations, and larger variability in wave height; (3) the last day, when the cold front fully reached the sampling area and abrupt changes in wind speed, $\mathrm{H}_{\mathrm{s}}$, and available nutrients followed rainfall and freshwater inflows. The characteristics of each period are summarized in Table 1.

Plankton dynamics: PCAs were also performed to determine patterns and shifts in the dynamics of the organisms (Fig. 5e,g). C1 (55\% of variability) was positively correlated to bacteria, cyanobacteria, and heterotrophic nanoflagellates, and was negatively correlated to chlorophyll and the fraction of chlorophyll $>10 \mu \mathrm{m}$. C2 (16\% of variability) was determined by autotrophic nanoflagellates and picoeukaryotes. The dynamics of chlorophyll were therefore dissociated from that of picoand nanoplankton, and the coupling between total chlorophyll and the fraction of chlorophyll $>10 \mu \mathrm{m}$ 

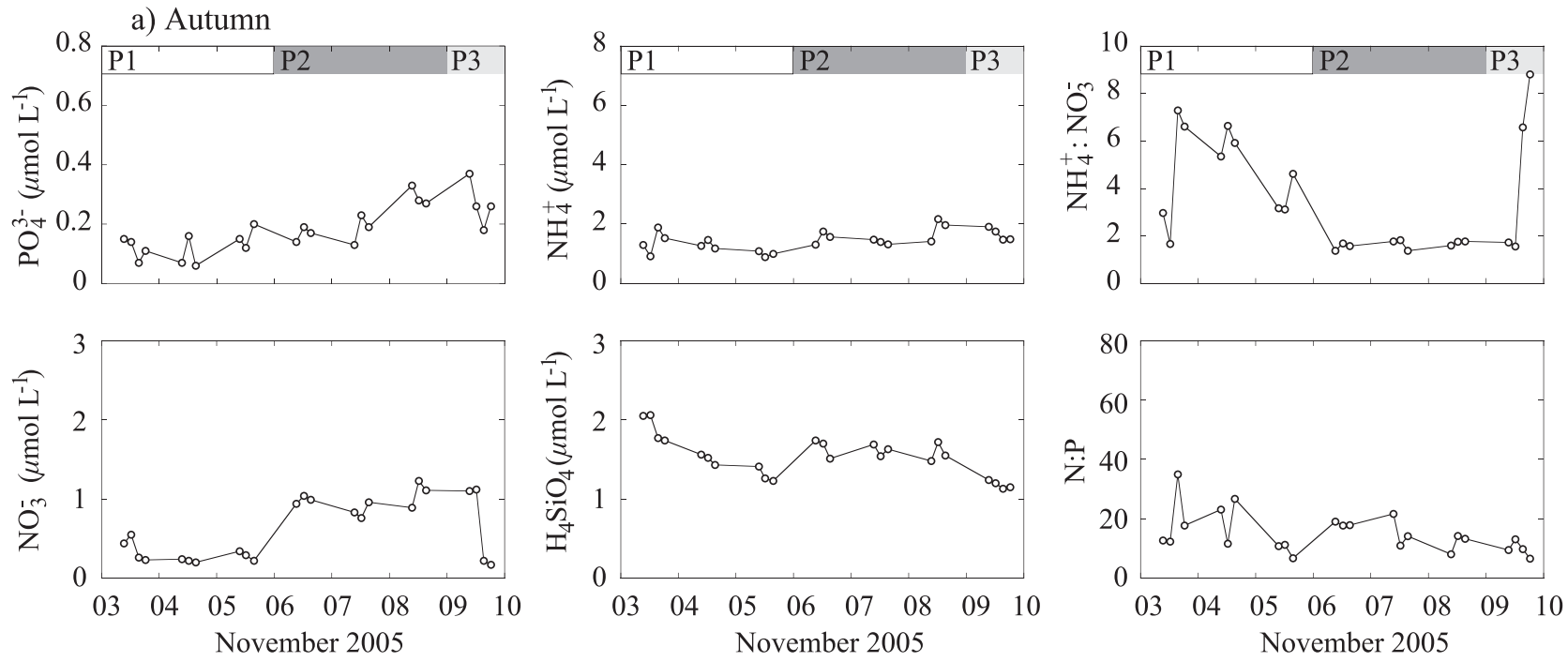

b) Spring
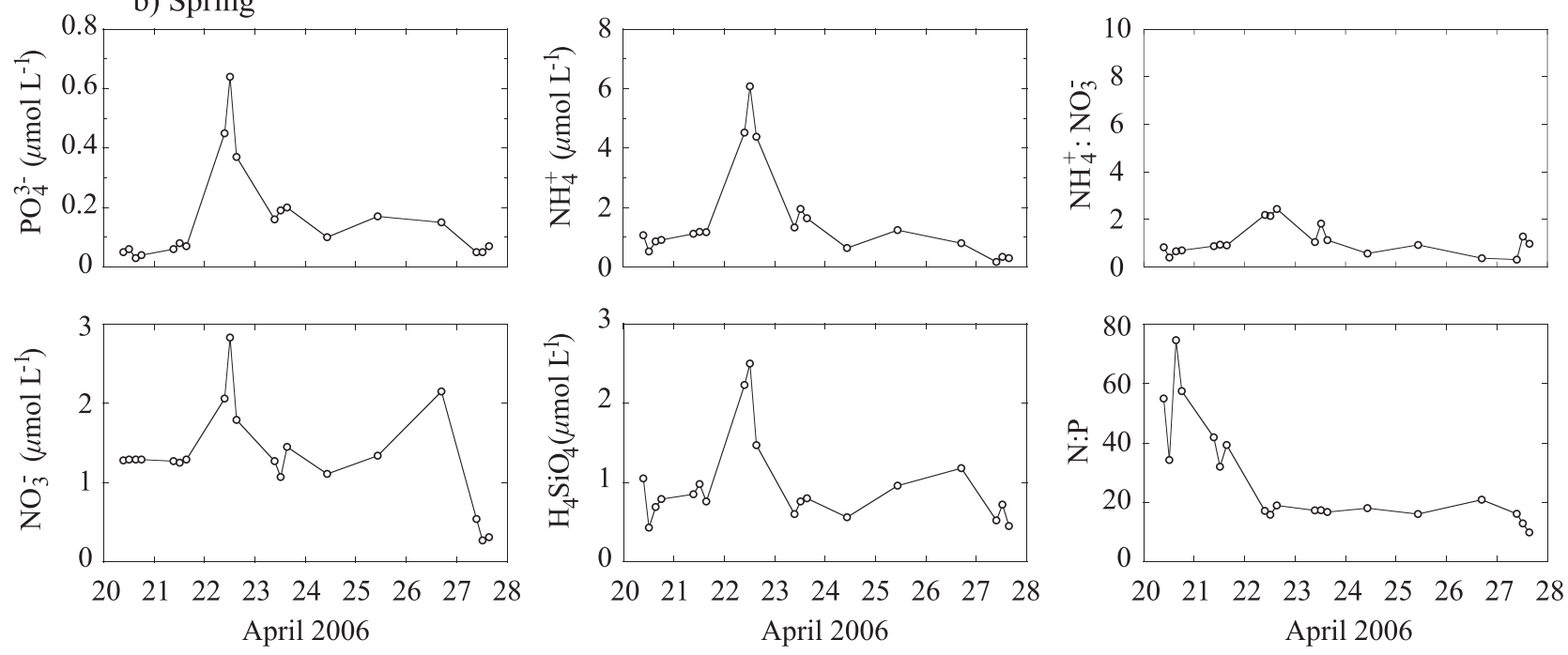

Fig. 4. Inorganic nutrients and related ratios during the (a) autumn and (b) spring survey: phosphate, nitrate, ammonium, silicate, the ratio $\mathrm{NH}_{4}^{+}: \mathrm{NO}_{3}^{-}$, and the ratio $\mathrm{N}: \mathrm{P}$, respectively. $\mathrm{P} 1, \mathrm{P} 2$, and $\mathrm{P} 3$ refer to the periods described in Table 1 for the autumn survey.

suggested that shifts in chlorophyll were mostly due to large phytoplankton. These trends could be also observed in the weekly time series (Fig. 6a-e): bacteria, cyanobacteria, and small flagellates were abundant during the first days but decreased afterwards, whereas chlorophyll seemed to respond positively to the rise in wind, waves, and nutrients observed during the middle days. Indeed, total microphytoplankton abundances increased over time (Fig. 7a), with a predominance of diatoms over the rest of groups during the last days of the survey (in terms of cell concentration, and notably in terms of biomass). Increases in chlorophyll and large autotrophic organisms boosted the concentration of particulate organic matter, and both POC and PON increased $\sim 30 \%$ with regard to the average value of the first $3 \mathrm{~d}$ (data not shown).

Correlation values between water column parameters are summarized in Table 2; these confirm the significant positive correlation between chlorophyll, nutrients, and
POC, and the negative correlation with bacteria, cyanobacteria, and nanoflagellates. Lagged correlations supported the observed trends, but added some information on the temporal match of the variables (Fig. 8). According to the cross correlations, there was an increase in phosphate and dissolved inorganic nitrogen $\left(\mathrm{NH}_{4}^{+}, \mathrm{NO}_{3}^{-}\right)$following increases in wind speed, but they were only significant after $\sim 24 \mathrm{~h}$ and up to $72 \mathrm{~h}$. No clear effects were seen for silicate. The positive effect of wind speed on chlorophyll (and particulate organic matter) and the overall negative effect on bacteria did also happen within a time frame of 24-72 h. Similar, but more confusing patterns were observed between wave height and water column parameters (not shown). Unclear effects of waves as compared to those of wind may be due to the high peak of $\mathrm{H}_{\mathrm{s}}$ at the very end of the survey, which likely biased the correlations, and to the fact that wind shifts related to daily breezes were not completely tuned in to changes in $\mathrm{H}_{\mathrm{s}}$, whose values 
Autumn
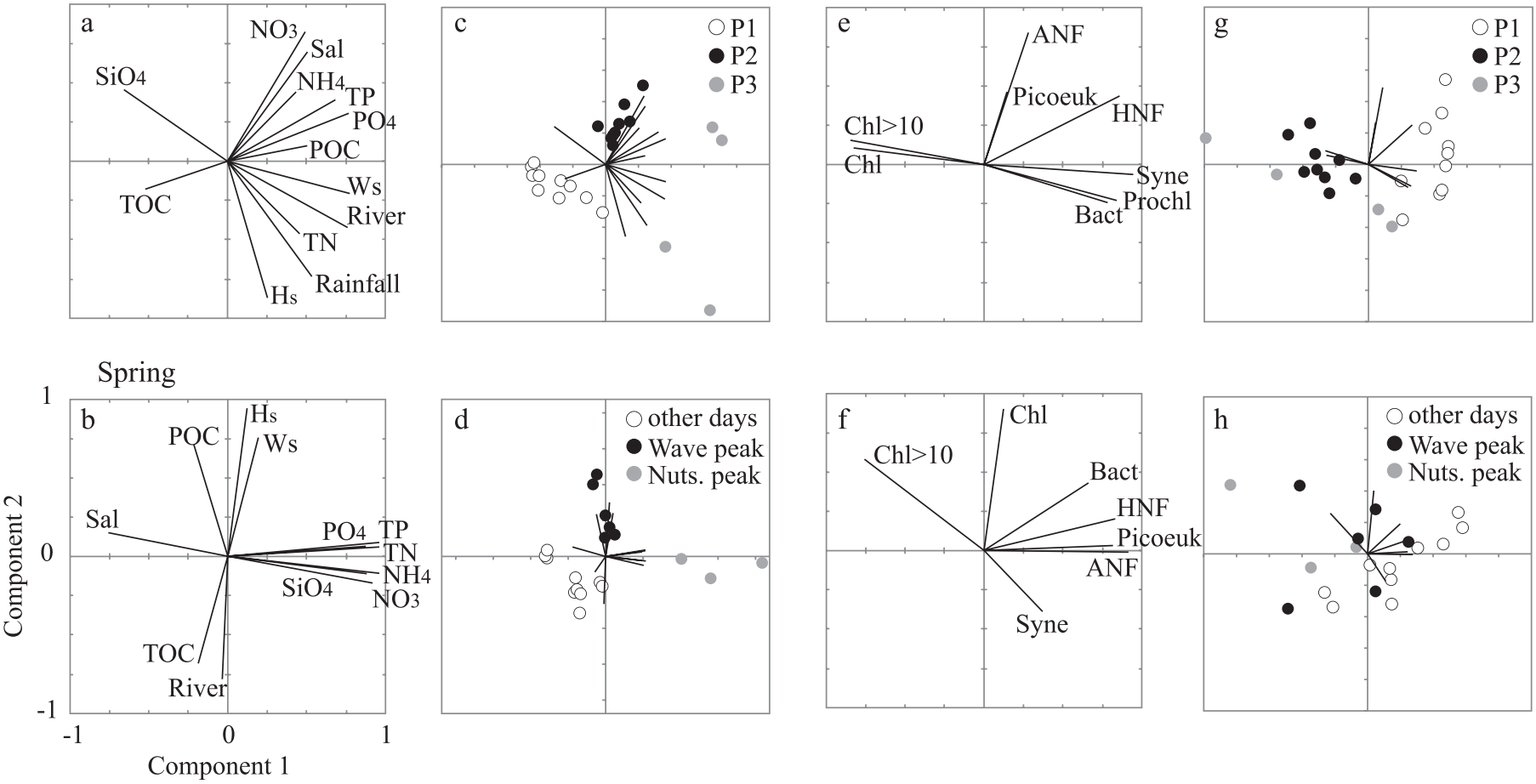

Fig. 5. Principal components analysis for the $(\mathrm{a}-\mathrm{d})$ physicochemical variables and $(\mathrm{e}-\mathrm{h})$ the log-transformed concentration of organisms in autumn and spring. The $\mathrm{x}$-axis represents Component 1 and the $y$-axis represents Component 2. (a, b, e, f) show the correlation coefficients of the different variables and vary between -1 and 1 ; (c, d, g, h) present the scores (eigenvalues) of each sampling for Components 1 and 2, and do not adjust to the range $(-1,1)$. Sampling points have been colored to identify different time periods during the surveys. P1, P2, and P3 refer to the periods described in Table 1. Wave peak refers to the interval 23-26 April, and nutrient (Nuts.) peak comprises the samplings on 22 April.

remained much steadier. Additional cross correlations were performed with rainfall and with the outflow of storm sewer pipes, but results proved inconsistent due to the lack of valid data: values for both variables were zero until the last day of the survey, and only two samplings took place afterwards.

Spring survey-Background conditions: The spring survey coincided with a low-pressure area in the northwest of the Iberian Peninsula (Catalan Meteorological Service monthly bulletins) and with sustained eastern winds that led to heavy seas and increased turbulence in the water (Fig. 2e-h). Wind increased steadily from 21-24 April, peaked in the morning of 24 April, and then decreased progressively until 27 April. Wave height showed the same pattern, even more distinctly, but it was slightly delayed with regard to wind (maximum $\mathrm{H}_{\mathrm{s}}$ occurred on the 25th). Sea breezes were minimal, although some day-night differences in wind direction were observable (Fig. 2f). Air temperature ranged from $10^{\circ} \mathrm{C}$ to $24^{\circ} \mathrm{C}$ and water temperature varied between $14.6^{\circ} \mathrm{C}$ and $16.7^{\circ} \mathrm{C}$. Some rainfall was recorded during the last day of the survey.

Table 1. Summary of environmental conditions during each of the three periods distinguished for the autumn sampling. Values in parentheses correspond to the average \pm standard deviation of the corresponding variable for the specific period.

\begin{tabular}{|c|c|c|c|c|c|}
\hline \multirow[b]{2}{*}{ Period } & \multirow[b]{2}{*}{ Physical conditions } & \multicolumn{4}{|c|}{ Concentration of nutrients $(\mu \mathrm{mol} \mathrm{L}-1)$} \\
\hline & & $\mathrm{PO}_{4}^{3-}$ & $\mathrm{NH}_{4}^{+}$ & $\mathrm{NO}_{3}^{-}$ & $\mathrm{H}_{4} \mathrm{SiO}_{4}$ \\
\hline P1, 03-05 Nov & $\begin{array}{l}\text { Low wind speed }\left(4.9 \pm 3.0 \mathrm{~m} \mathrm{~s}^{-1}\right) \\
\text { West-southwest winds } \\
\text { Low-moderate waves }\left(\mathrm{H}_{\mathrm{s}}=0.5 \pm 0.1 \mathrm{~m}\right)\end{array}$ & $0.12 \pm 0.05$ & $1.25 \pm 0.31$ & $0.30 \pm 0.11$ & $1.60 \pm 0.29$ \\
\hline P2, 06-08 Nov & $\begin{array}{l}\text { Moderate wind speed }\left(6.2 \pm 2.9 \mathrm{~m} \mathrm{~s}^{-1}\right) \\
\text { Regular breeze regime } \\
\text { Low-moderate waves }\left(\mathrm{H}_{\mathrm{s}}=0.4 \pm 0.1 \mathrm{~m}\right)\end{array}$ & $0.23 \pm 0.08$ & $1.64 \pm 0.29$ & $1.00 \pm 0.14$ & $1.55 \pm 0.18$ \\
\hline P3, 09 Nov & $\begin{array}{l}\text { High wind speed }\left(7.4 \pm 2.4 \mathrm{~m} \mathrm{~s}^{-1}\right) \\
\text { North, east winds } \\
\text { Moderate-high waves }\left(\mathrm{H}_{\mathrm{s}}=0.8 \pm 0.5 \mathrm{~m}\right) \\
\text { Rainfall }\end{array}$ & $0.22 \pm 0.05$ & $1.48 \pm 0.01$ & $0.20 \pm 0.04$ & $1.14 \pm 0.01$ \\
\hline
\end{tabular}



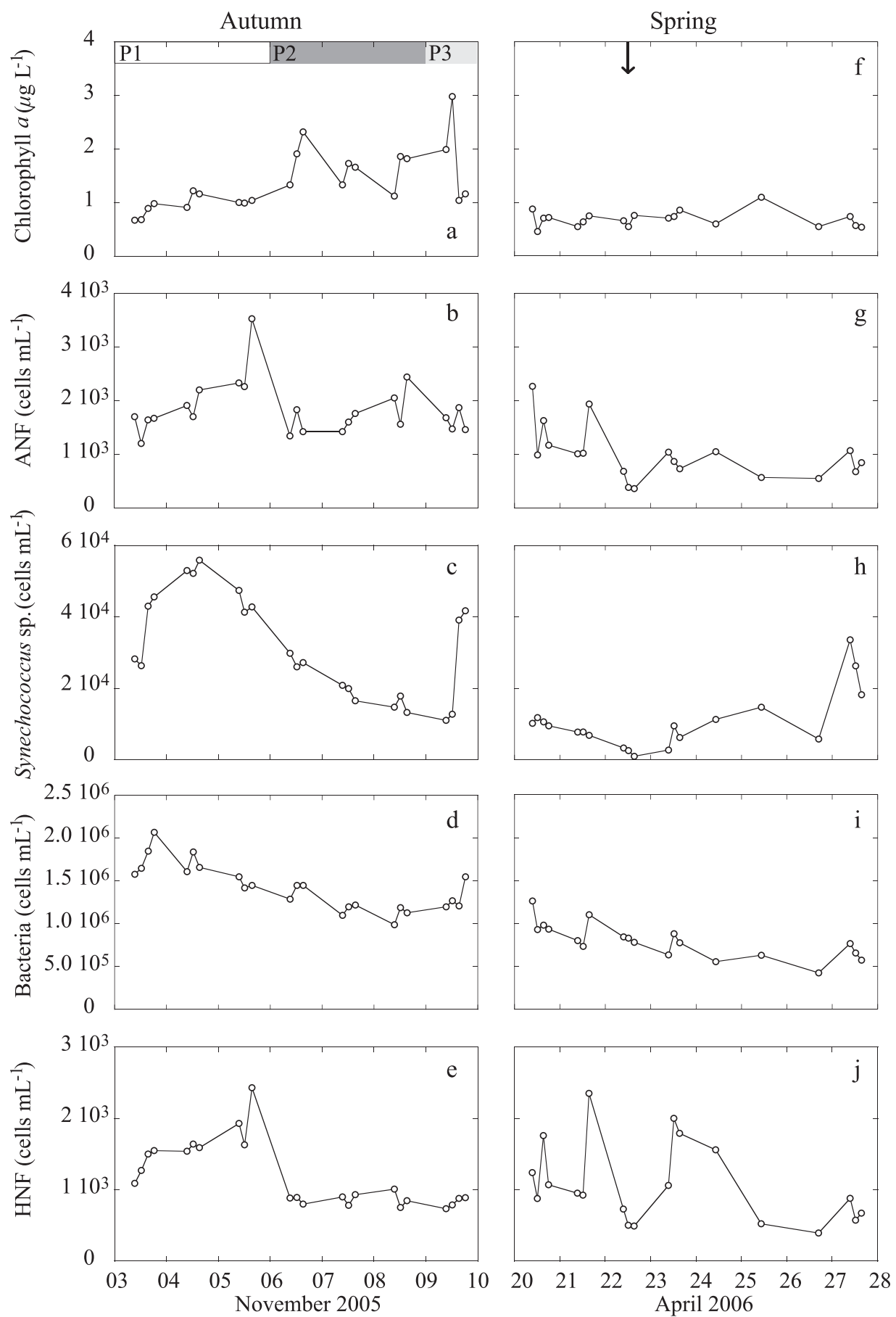

Fig. 6. Day-to-day dynamics of several groups of plankton during the (a-e) autumn and (f-j) spring survey. (a, f) Chlorophyll $a,(\mathrm{~b}, \mathrm{~g})$ autotrophic nanoflagellates, $(\mathrm{c}, \mathrm{h})$ Synechococcus sp., (d, i) heterotrophic bacteria, and (e, j) heterotrophic nanoflagellates. P1, P2, and P3 refer to the periods described in Table 1 for the autumn survey. The black arrow marks the nutrient peak in spring.

Nutrient availability: Nutrient concentrations remained stable during the first $2 \mathrm{~d}$, increased suddenly between $21-$ 22 April, and decreased to circa the initial values on 23 April (Fig. 4). Along with the nutrient maximum there was an increase in TP, TN, and to a lesser extent, TOC (not shown). Strikingly, the ephemeral nutrient peak did not match a clear physical perturbation; wave height, rainfall, atmospheric dry deposition (data not shown), and the storm sewer outflow did not show simultaneous increases. Nonetheless, some variations in the CTD salinity profiles (Fig. 3) hint at a short-lived freshwater spill that may have occurred on 22 April, affecting the first meters of the water 

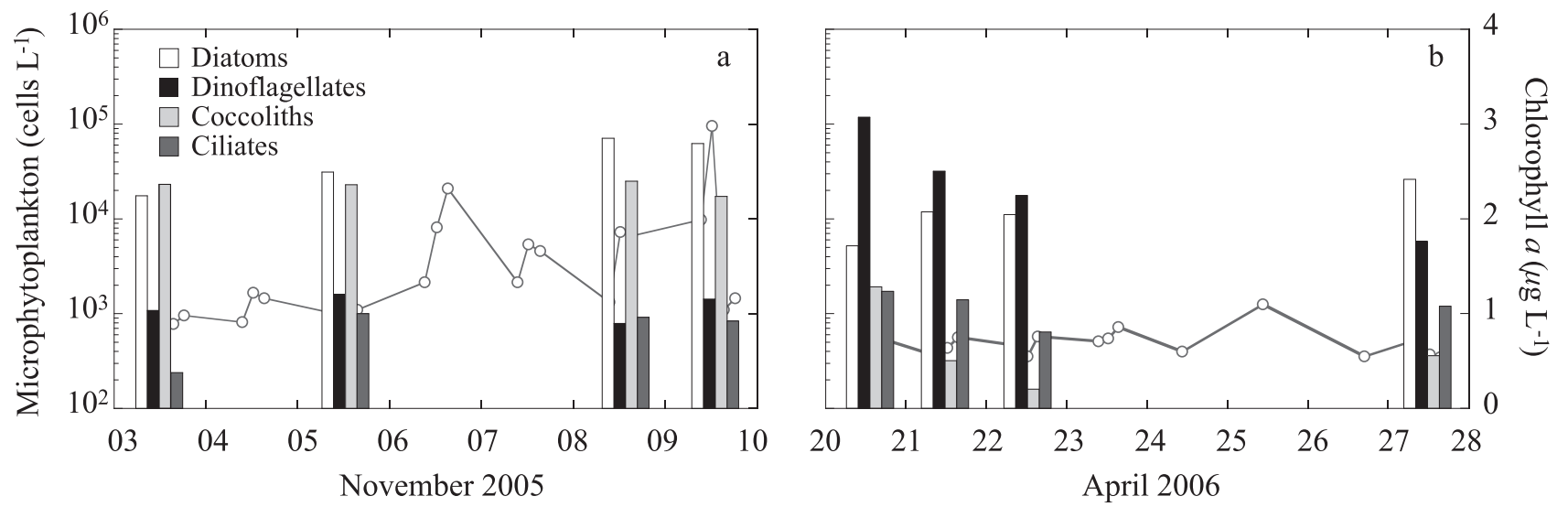

Fig. 7. Concentration of the most abundant microphytoplankton groups in (a) autumn and (b) spring. Chlorophyll values throughout the surveys are plotted in the back for reference (gray line).

column. Indeed, the nutrient input peak showed a sewagelike signature and the concomitant salinity drop was observable in the shallower station but blurred at the deeper station, suggesting that the plume came from inshore waters. Following the slackening of eastern winds and shortly after $\mathrm{H}_{\mathrm{s}}$ reached its maximum on 25 April, some nutrients increased again, particularly nitrate and silicate (Fig. 4). This secondary peak coincided with an increase in particulate organic matter (POC and PON, not shown); consistently, an increase in turbidity could be

Table 2. Correlation coefficients $(r)$ for regressions between water column parameters during the two surveys. Only significant correlations $(p<0.05)$ are shown. Abbreviations: Chl $=$ chlorophyll $a$, Chl $>10=$ chlorophyll $a>10 \mu \mathrm{m}$, Syne $=$ Synechococcus sp., Peuk $=$ picoeukaryotes, Bact $=$ heterotrophic bacteria, $\mathrm{ANF}=$ autotrophic nanoflagellates, $\mathrm{HNF}=$ heterotrophic nanoflagellates, $\mathrm{TB}=$ total carbon biomass. Carbon biomass was estimated applying the conversion factors specified in the text. Total carbon biomass is calculated by the addition of algae - derived from chlorophyll $a$-bacteria, and heterotrophic nanoflagellates.

\begin{tabular}{|c|c|c|c|c|c|c|c|c|c|c|c|c|c|c|c|}
\hline Parameter & $\mathrm{NH}_{4}$ & $\mathrm{NO}_{3}$ & $\mathrm{SiO}_{4}$ & Chl & $\mathrm{Chl}>10$ & Syne & Peuk & Bact & $\mathrm{ANF}$ & HNF & TOC & $\mathrm{TN}$ & $\mathrm{TP}$ & POC & $\mathrm{TB}$ \\
\hline \multicolumn{16}{|l|}{ Autumn } \\
\hline $\mathrm{PO}_{4}$ & 0.48 & 0.61 & & 0.53 & 0.58 & -0.72 & & -0.65 & & -0.51 & -0.44 & & 0.56 & & \\
\hline $\mathrm{NH}_{4}$ & & 0.57 & & 0.58 & 0.50 & -0.47 & & & & -0.59 & & & & & 0.52 \\
\hline $\mathrm{NO}_{3}$ & & & & 0.76 & 0.70 & -0.90 & & -0.68 & & -0.72 & & & 0.70 & 0.43 & 0.64 \\
\hline $\mathrm{SiO}_{4}$ & & & & & & & & & & & & -0.49 & & & \\
\hline Chl & & & & & 0.94 & -0.61 & & -0.45 & & -0.57 & -0.43 & & 0.62 & 0.57 & 0.95 \\
\hline $\mathrm{Chl}>10$ & & & & & & -0.63 & & -0.49 & & -0.53 & -0.53 & & 0.62 & 0.51 & 0.89 \\
\hline Syne & & & & & & & & 0.75 & & 0.74 & & & -0.70 & & -0.48 \\
\hline Peuk & & & & & & & & & & & & & & & \\
\hline Bact & & & & & & & & & & 0.58 & & & -0.74 & -0.44 & \\
\hline ANF & & & & & & & & & & 0.68 & & & & & \\
\hline HNF & & & & & & & & & & & & & -0.57 & -0.55 & -0.43 \\
\hline \multirow{2}{*}{\multicolumn{16}{|c|}{$\begin{array}{l}\text { TOC } \\
\text { TN }\end{array}$}} \\
\hline & & & & & & & & & & & & & & & \\
\hline TP & & & & & & & & & & & & & & & 0.47 \\
\hline POC & & & & & & & & & & & & & & & 0.45 \\
\hline \multicolumn{16}{|l|}{ Spring } \\
\hline $\mathrm{PO}_{4}$ & 0.96 & 0.77 & 0.88 & & & -0.50 & & & -0.55 & & & 0.88 & 0.85 & & \\
\hline $\mathrm{NH}_{4}$ & & 0.79 & 0.91 & & & -0.58 & & & & & & 0.89 & 0.83 & & \\
\hline $\mathrm{NO}_{3}$ & & & 0.83 & & & -0.73 & & & & & & 0.81 & 0.67 & & \\
\hline $\mathrm{SiO}_{4}$ & & & & & & -0.48 & & & & & & 0.88 & 0.69 & & \\
\hline Chl & & & & & 0.55 & & & & & & & & & 0.48 & 0.65 \\
\hline Chl $>10$ & & & & & & & & -0.46 & -0.57 & & & & & & \\
\hline Syne & & & & & & & & & & & & -0.53 & -0.55 & & \\
\hline Peuk & & & & & & & & & 0.57 & 0.48 & & & & & 0.54 \\
\hline Bact & & & & & & & & & 0.66 & & & & & & 0.45 \\
\hline ANF & & & & & & & & & & 0.60 & & & & & 0.46 \\
\hline HNF & & & & & & & & & & & & & & & 0.52 \\
\hline TOC & & & & & & & & & & & & & & & \\
\hline $\mathrm{TN}$ & & & & & & & & & & & & & 0.70 & & \\
\hline TP & & & & & & & & & & & & & & & \\
\hline POC & & & & & & & & & & & & & & & \\
\hline
\end{tabular}


a) Autumn

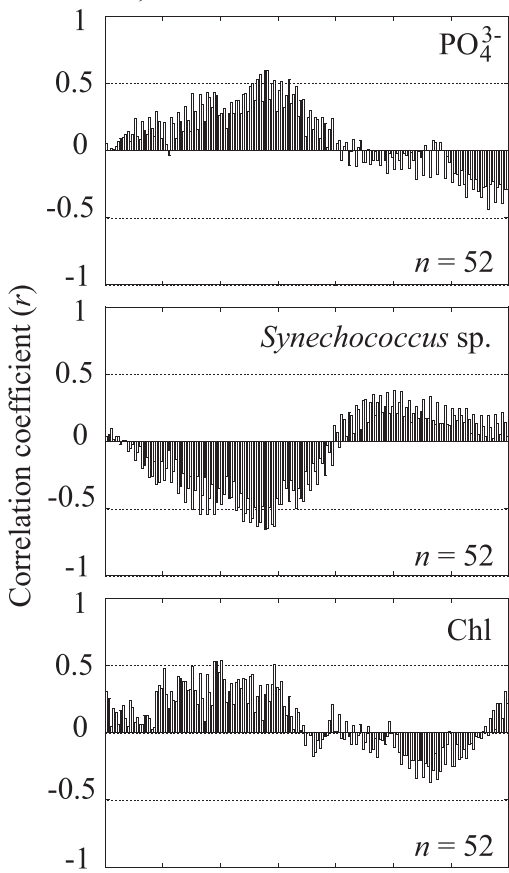

b) Spring
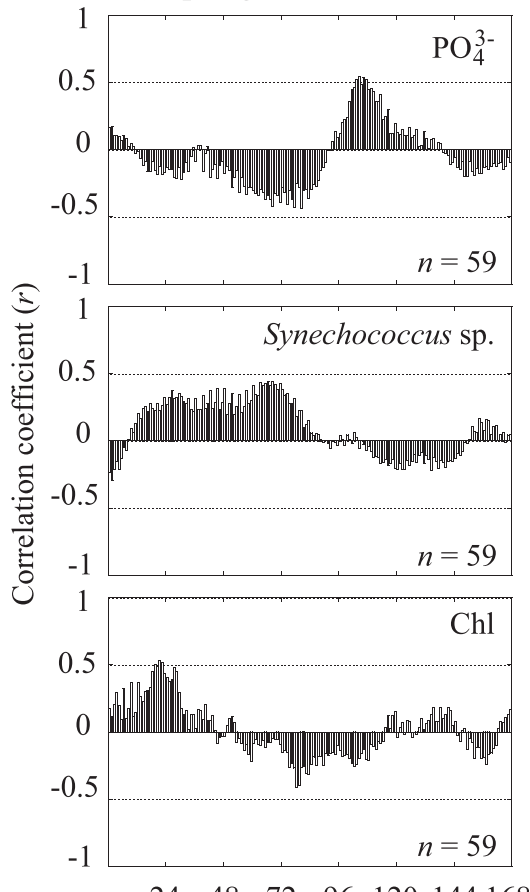
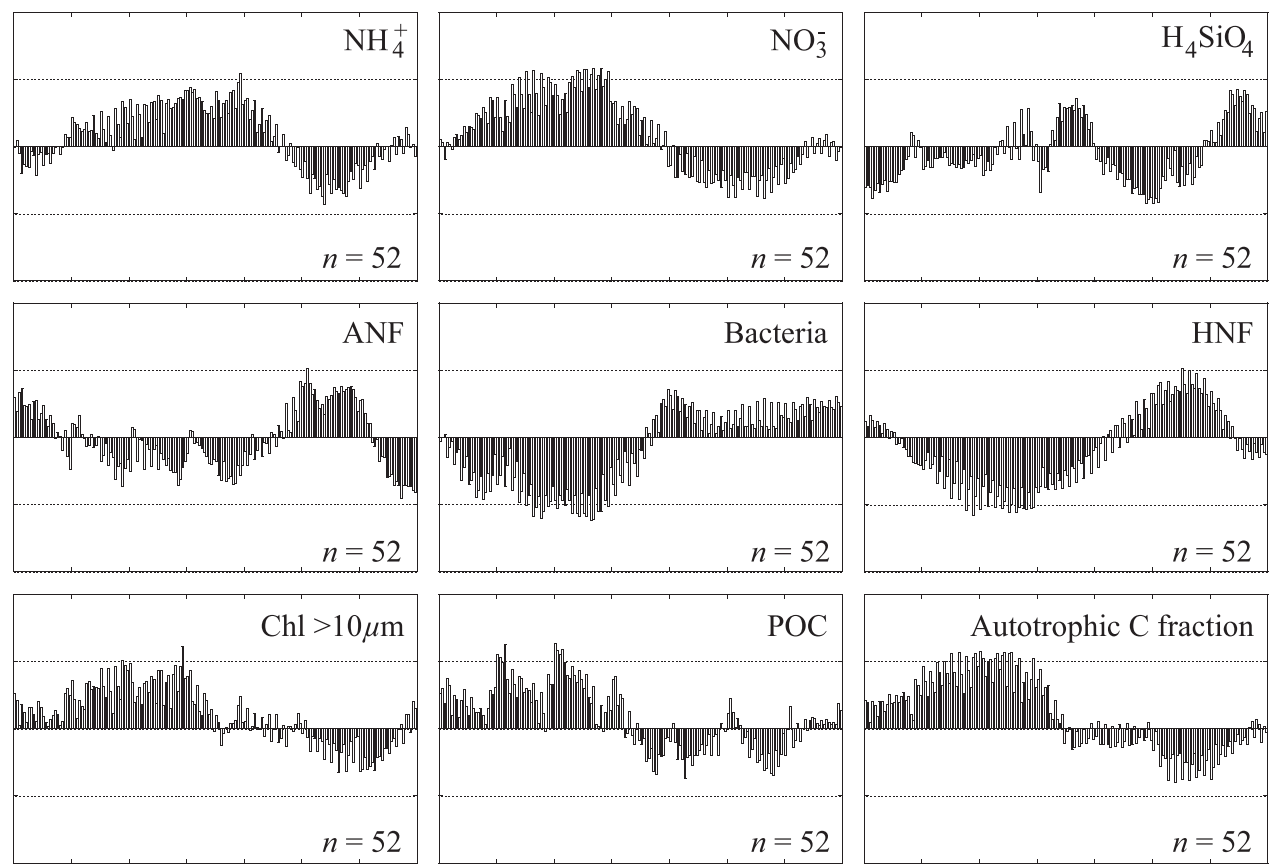

$n=52$
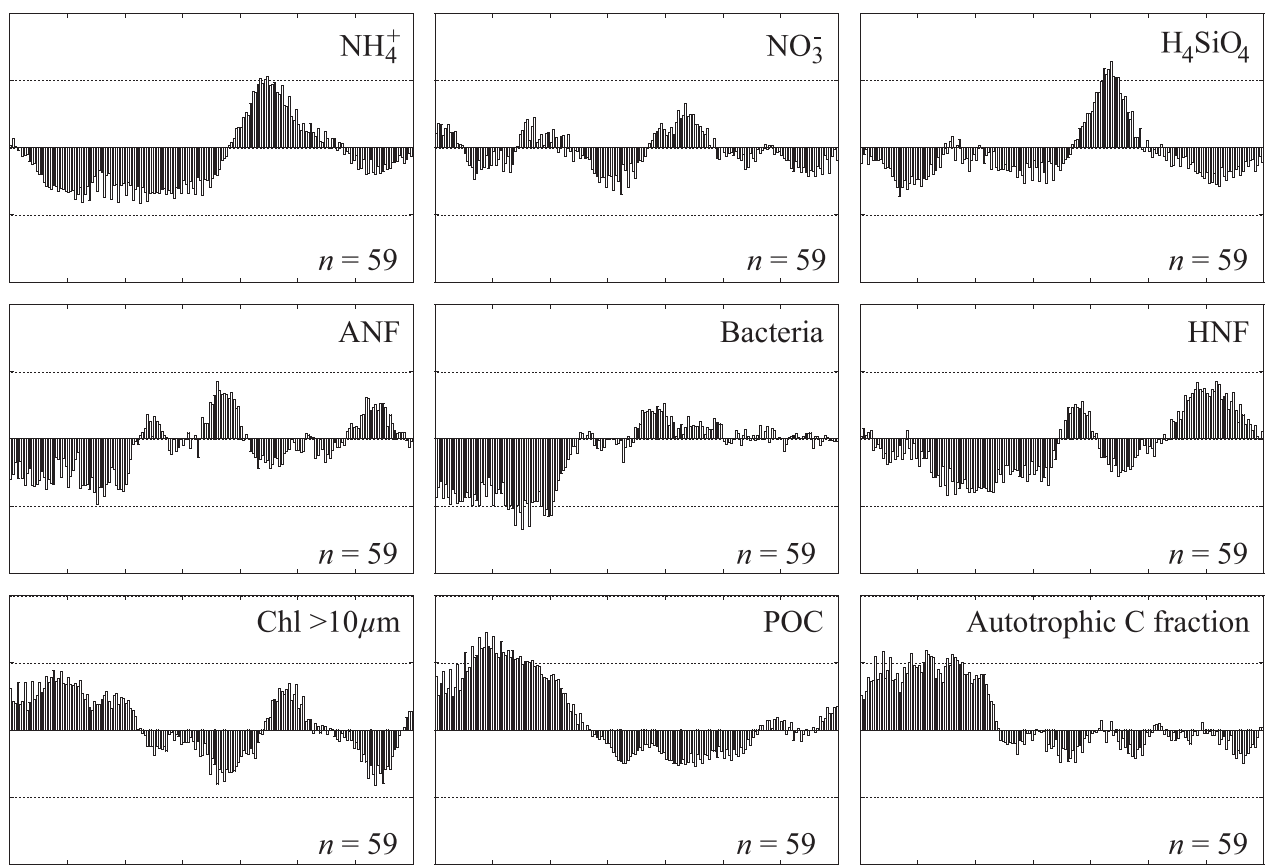

$\begin{array}{lllllll}24 & 48 & 72 & 96 & 120 & 144 & 168\end{array}$

$\begin{array}{lllllll}24 & 48 & 72 & 96 & 120 & 144 & 168\end{array}$

$\begin{array}{lllllll}24 & 48 & 72 & 96 & 120 & 144 & 168\end{array}$

Time lag (h)

Fig. 8. Cross correlations between high-frequency wind speed data and the biological and chemical data set coming from the samplings. (a) In the autumn survey, the threshold for significance $(p<0.05)$ is $r>0.2734$; (b) in the spring survey, the threshold for significance $(p<0.05)$ is $r>0.2563$.

noticed in the CTD profiles. High seas likely induced some sediment resuspension, since turbidity was high near the bottom but diminished upwards.

Nutrient and elemental ratios were substantially different between these two nutrient peaks (Fig. 4). During the first nutrient injection, $\mathrm{NH}_{4}^{+}: \mathrm{NO}_{3}^{-}$reached values close to $\sim 2.5$ and $\mathrm{N}: \mathrm{P}$ decreased from $\sim 50$ to $\sim 16$, indicating large relative inputs of ammonium and phosphate. In contrast, ratios barely changed after the resuspension event (26 April) and the highest nutrient increases corresponded to nitrate and silicate. 
The PCA analysis further supported the occurrence of two separate forcing episodes in spring (Fig. 5b). The first component $(\mathrm{C} 1,49 \%$ variability) was positively determined by nutrients, TN, and TP, and negatively correlated to salinity. It hence pointed at the freshwater spill on 22 April. Component 2 (C2, 24\% variability) was positively linked to wind speed, wave height, and POC, and negatively linked to river discharge and TOC, which hints at the resuspension episode. Note that the moderate increase in nutrients (notably nitrate and silicate) that accompanied the resuspension was completely overshadowed in the PCA by the isolated nutrient peak on 22 April. Plotting each sampling score on the space defined by the two components, the two separate events stood out clearly (Fig. 5d).

Plankton dynamics: The partial mismatch between nutrient inputs and wave height led to divergent biological responses after both episodes. Unexpectedly, the large nutrient peak on 22 April did not seem to stimulate biological growth (Fig. $6 \mathrm{f}-\mathrm{j}$ ). Most pico- and nanoplankton, both heterotrophic and autotrophic, decreased, chlorophyll values remained steady, and only a moderate increase of chlorophyll $>10 \mu \mathrm{m}$ was observed. On the contrary, increased water motion tallied with nitrate and silicate inputs induced a positive response of autotrophs (total chlorophyll peaked on 25 April) and none or slightly negative effects on heterotrophic organisms. Microphytoplankton counts (Fig. 7b) showed a decrease in the total number of cells and a progressive shift from dinoflagellates to diatoms throughout the sampling week. PCA results showed a separation between pico- and nanoplankton and chlorophyll measurements, notably with the fraction of chlorophyll $>10 \mu \mathrm{m}$ (Fig. 5f,h); overlapping the scores of the samplings on the vector space, however, organisms' patterns could not be ascribed to temporal intervals as clearly as it happened with the physicochemical factors.

Table 2 shows the correlation values between water column parameters during the spring survey. Inorganic nutrients, $\mathrm{TN}$, and $\mathrm{TP}$ were correlated to each other but were not significantly related to the abundance of organisms, except for some negative correlations with Synechococcus sp. and autotrophic nanoflagellates. Total C biomass was significantly related to several groups of organisms (chlorophyll, bacteria, picoeukaryotes, and autotrophic and heterotrophic nanoflagellates), hinting at a significant contribution of the whole community to the carbon stock, which is often completely biased by specific dominant groups. This supports the idea that none of the planktonic groups completely outweighed the others as a result of environmental disturbances.

Provided that we did not have any rainfall or measurable storm sewer efflux until the last day of the spring survey, cross correlations could only be used to assess the effects of wind speed and wave height. Both physical variables were indeed strongly correlated: the peak in $\mathrm{H}_{\mathrm{s}}$ occurred $24 \mathrm{~h}$ after the peak in wind velocity (Fig. 2), so the results were similar with slightly larger lags for wind speed. To maintain consistency and ease comparisons between surveys, only cross correlations with wind speed are presented (Fig. 8). Systematic negative correlations appeared between wind speed and inorganic nutrients during the first $72 \mathrm{~h}$, although the negative relationship was low and weakly significant for silicate and nitrate (for nitrate, some positive correlation coefficients appeared within the first day). Wind speed was also negatively correlated to TP during the first days (not shown), but induced immediate increases in particulate organic matter: POC showed strong positive correlations within the first $48 \mathrm{~h}$. Overall, wind speed and heavy seas seemed to stimulate large autotrophs within a short period of time (there was a positive correlation with chlorophyll, and particularly with chlorophyll $>10 \mu \mathrm{m}$ ), whereas small eukaryotes, pigmented nanoflagellates, bacteria, and heterotrophic flagellates showed persistent negative correlations.

\section{Discussion}

Nutrient inputs coupled to increased wave height-Two episodes with concurrent increases in mixing and nutrient inputs were observed, one in autumn and the other in spring. Although there were differences in the intensity of the forcing, the load of nutrients, and the receiving communities (analysis of similarity test for differences in the composition of the initial communities, $p<0.05$ ), the biological outcome showed similarities. Broadly, recycling processes and various groups of small-sized organisms dominated the system before both episodes. The consortium between bacteria and small phytoplankton prevails during most of the year in many oligotrophic regions (Margalef et al. 1979; Longhurst 2007). Increased waves and mixing were related to intensified daily breezes (autumn) and persistent eastern winds (spring), which in turn led to moderate nutrient inputs and some resuspension. These are common phenomena in most coastal areas at any time of the year, so the correspondent community changes may be equally frequent. Note that the concurrence of waves and nutrients was not obvious in the PCA because larger uncoupled peaks of both variables $\left(\mathrm{H}_{\mathrm{s}}\right.$ in autumn and nutrients in spring) occurred during the surveys that strongly dominated the principal components.

The overlap of turbulence and nutrients and the relative nutrient composition (with abundant $\mathrm{N}_{-} \mathrm{NO}_{3}^{-}$and $\mathrm{Si}$ ) stimulated the autotrophic component, and particularly diatoms, over other organisms. This biological response showed up very clearly in the PCA scores in autumn (Fig. 5g), and somewhat less in spring. A number of factors could have acted toward the benefit of large phytoplankton cells: (1) moderate water movements prevent sinking of large cells and allow for longer sustained growth (Thingstad and Rassoulzadegan 1999; Huisman et al. 2002); (2) some resuspension of diatom cysts or other benthic algae might have occurred (Smetacek 1985), particularly during the spring survey. Nevertheless, CTD profiles in spring showed that the turbidity signal was weaker than the fluorescence signal and the latter went farther up in the water column, suggesting some stimulation and active growth in the upper layers; (3) under diffusion-limited conditions, small-scale turbulence increases nutrient uptake of osmotrophic cells (Lazier and Mann 1989; Karp-Boss et al. 1996) and the effect is proportional to cell size, so it 
favors large over small organisms (Karp-Boss et al. 1996; Peters et al. 2006); (4) in addition to silicate, previous studies have shown the accordance between diatom abundance and nitrate concentration, so the fact that the largest nutrient increases corresponded to nitrate could have further benefited diatoms over other groups (Eppley et al. 1969; Stolte et al. 1994; Romero et al. 2012). Örnólfsdóttir et al. (2004) observed systematic shifts toward diatom dominance in a series of experimental bioassays where natural communities were subjected to nitrate enrichments. The predominance of diatoms occurred even when such communities were initially dominated by cyanobacteria. Some other studies have pointed out a correspondence between nitrate inputs and diatom bursts in the field (Riegman and Noordeloos 1998; Riegman et al. 1998; Mercado et al. 2008).

Further, the community evolved toward a larger abundance of autotrophs and diatom-rich assemblages within similar time lags in both surveys (Fig. 8). Although we cannot completely preclude the possibility that shifts in planktonic groups were directly caused by the advection of offshore waters, various factors suggest that the observed changes were indeed the response of the local community to the physicochemical forcing. As noted by Pannard et al. (2008a), if changes in species or groups' composition were due to water advection, then one could expect to observe a high short-term variability of both physical, chemical, and biological properties, with changes occurring in phase (no time lags). This was not the case in our study: biological changes were not synchronous to variations in the environmental conditions, but they were somewhat delayed. In autumn, nutrient increases occurred between 05 and 06 November, whereas chlorophyll increases were more gradual and maximum values were found in the afternoon of 06 November. In spring, wave height peaked on 24-25 April but chlorophyll increases were observed on the 25th. Similar time lags were observed for autotrophic organisms as a response to mixing and nutrient inputs by Pannard et al. (2008a). Collos (1986) found that time lags before the onset of cell division varied between a few minutes to $24 \mathrm{~h}$ depending on species strategies, as a function of growth response vs. storage response. Consequently, the observed delays in biological parameters were within realistic ranges. Moreover, there was little variation in the phytoplankton community before and after the nutrient inputs in terms of species composition (Leptocylindrus danicus, Chaetoceros spp., and small coccolithophores $[<10 \mu \mathrm{m}]$ in autumn; Pseudo-nitzschia spp., Chaetoceros spp., pennate diatoms, Scripsiella sp., and dinoflagellates $<25 \mu \mathrm{m}$ in spring); only changes in the abundance of species were observed. This again supports the idea that biological shifts were due to the response of the local microbial community.

A side issue during episodes of increased mixing is the fact that turbulence can induce sediment resuspension and reduce light availability within the water, thus acting against the response of autotrophs. Some resuspension of bed sediments (coarse sand) did occur during the spring event, although that did not hamper phytoplankton growth. Despite some transient light attenuation owing to resuspension, light always reaches the bottom of the water column in our system (Romero 2010). The fact that light limitation is not a serious drawback for phytoplankton growth in our sampling area makes it somewhat different from other locations. Grémare et al. (2003) followed a strong winter storm in the bay of Banyuls-sur-mer (northwest Mediterranean). In their study, rough seas generated a resuspension event that abruptly increased total suspended matter and nutrients in the water column. Increased turbidity affected the competition outcome between planktonic organisms: whereas production and biomass of bacterioplankton were significantly enhanced, no response of phytoplanktonic cells was observed, presumably as a result of light attenuation. Contrary to their results, the resuspension event in our study area did not primarily foster bacterial growth but rather induced a slight increase of phytoplankton. Apart from light availability, some other specific conditions distinguished both cases: (1) their wave peak was greater $\left(\mathrm{H}_{\mathrm{s}}\right.$ exceeded $\left.6 \mathrm{~m}\right)$, and thus the volume of resuspended material might have been considerably larger; (2) rough seas in Banyuls were shorter in time ( 2 vs. $5 \mathrm{~d}$ ), so that the period of increased nutrient availability may have been too short to enhance phytoplanktonic production; (3) bottom sediments in our sampling area are mostly loose, coarse sands that rapidly settle down, whereas finer sediments, and thus longer lasting turbidity, may be found in Banyuls; (4) Grémare et al. (2003) suggest a possible deficiency of continental inputs (i.e., silicate) in Banyuls, which may have further constrained autotrophic growth that did not occur during our sampling. The combination of lasting, lower turbulence intensities along with available silicate could explain the preferential response of phytoplankton cells.

Nutrient inputs dissociated from increased wave heightIn contrast with these episodes of matching increases in waves and nutrients, a transient nutrient pulse dissociated from increased waves occurred in spring, on the third day of the survey. Both the briefness of the signal and the relative nutrient composition - particularly rich in ammonium and phosphate - hinted at a waste spill from the nearby drainage pipes, moderate in volume but rather concentrated in nutrients. Salinity drops were apparent in the uppermost layer of the corresponding CTD profiles, and the disturbance was particularly evident in the stations closest to land, suggesting that the plume came from inshore waters.

We checked whether the nutrient injection could correspond to atmospheric inputs. Studies addressing atmospheric deposition in the northwest Mediterranean basin (Guerzoni et al. 1999; Sanz et al. 2002) have pointed out that atmospheric fluxes may contribute extensively to nutrient supply in coastal urbanized areas, because anthropogenic emissions are rich in $\mathrm{N}$ and $\mathrm{P}$ species (i.e., $\mathrm{NO}_{\mathrm{x}}$ from industrial combustion and vehicle traffic, $\mathrm{HNO}_{3}$ from vehicle traffic, $\mathrm{P}$ compounds from incinerators and domestic and industrial substances). We found significant inputs of ammonium and nitrate; silicate deposition was also abundant, and was likely related to dust clouds from nearby construction works. However, estimated nutrient 
Table 3. Basic statistics for several physical, chemical, and biological parameters measured during the two intensive surveys, and their corresponding values for a multiyear time series of monthly samplings. $\mathrm{M}=$ mean, $\mathrm{SE}=$ standard error. The range of values (Min.Max.) divided by the mean (RelVar) was used as an estimate of relative variation within each period. The multiyear time series comprised data for a $7 \mathrm{yr}$ period (2002-2008, $n=69)$ except for $\mathrm{Chl}>10 \mu \mathrm{m}(\mathrm{Chl}>10)$, bacteria, and POC, which were only available for $3 \mathrm{yr}(2005$ 2008, $n=34$ ). Wind speed (Ws) is in units of $\mathrm{m} \mathrm{s}^{-1}, \mathrm{H}_{\mathrm{s}}$ in $\mathrm{m}$, nutrients and POC are in $\mu \mathrm{mol} \mathrm{L}-1$, Chl is $\mu \mathrm{g} \mathrm{L}-1$, and bacterial abundances are in $10^{6}$ cells $\mathrm{mL}^{-1}$.

\begin{tabular}{|c|c|c|c|c|c|c|c|c|c|c|c|c|}
\hline \multirow[b]{2}{*}{ Variable } & \multicolumn{4}{|c|}{ Autumn survey, 03-09 Nov 2005} & \multicolumn{4}{|c|}{ Spring survey, 20-27 Apr 2006} & \multicolumn{4}{|c|}{ Multiyear time series, 2002-2008 } \\
\hline & M & SE & Min.-Max. & RelVar & M & SE & Min.-Max. & $\overline{\text { RelVar }}$ & $M$ & SE & Min.-Max. & RelVar \\
\hline$\overline{\mathrm{Ws}}$ & 5.8 & 0.2 & $0.9-11.7$ & 1.9 & 4.8 & 0.2 & $0.3-10.5$ & 2.1 & 4.2 & 0.01 & $0-19.9$ & 4.8 \\
\hline $\mathrm{H}_{\mathrm{s}}$ & 0.49 & 0.02 & $0.21-1.59$ & 2.8 & 0.77 & 0.03 & $0.21-1.90$ & 2.2 & 0.67 & 0.01 & $0.11-3.75$ & 5.4 \\
\hline $\mathrm{PO}_{4}^{3-}$ & 0.18 & 0.02 & $0.06-0.37$ & 1.7 & 0.16 & 0.04 & $0.03-0.64$ & 3.9 & 0.19 & 0.01 & $0.03-0.47$ & 2.4 \\
\hline $\mathrm{NH}_{4}^{+}$ & 1.46 & 0.07 & $0.89-2.17$ & 0.9 & 1.59 & 0.37 & $0.17-6.08$ & 3.7 & 1.92 & 0.17 & $0.20-7.66$ & 3.9 \\
\hline $\mathrm{NO}_{3}^{-}$ & 0.62 & 0.08 & $0.17-1.23$ & 1.7 & 1.32 & 0.14 & $0.27-2.83$ & 1.9 & 1.04 & 0.10 & $0.07-5.03$ & 4.8 \\
\hline $\mathrm{H}_{4} \mathrm{SiO}_{4}$ & 1.53 & 0.05 & $1.13-2.06$ & 0.6 & 0.96 & 0.13 & $0.43-2.50$ & 2.1 & 0.93 & 0.05 & $0.23-2.23$ & 2.1 \\
\hline Chl & 1.38 & 0.12 & $0.67-2.98$ & 1.7 & 0.68 & 0.03 & $0.46-0.99$ & 0.8 & 1.58 & 0.13 & $0.29-6.63$ & 4.0 \\
\hline $\mathrm{Chl}>10$ & 0.67 & 0.09 & $0.22-2.20$ & 3.0 & 0.22 & 0.03 & $0.11-0.51$ & 1.8 & 0.60 & 0.09 & $0.02-1.95$ & 3.2 \\
\hline Bacteria & 1.43 & 0.06 & $0.99-2.07$ & 0.8 & 0.79 & 0.05 & $0.42-1.26$ & 1.1 & 1.25 & 0.06 & $0.64-2.12$ & 1.2 \\
\hline $\mathrm{POC}$ & 23.3 & 1.1 & $14.7-34.8$ & 0.9 & 22.1 & 1.4 & $12.1-39.6$ & 1.2 & 19.9 & 1.8 & $7.3-41.4$ & 1.7 \\
\hline
\end{tabular}

increases for a $10 \mathrm{~m}$ water column were minor $(\sim 7-10 \%$ maximum increase) and could not explain the sudden nutrient pulse found during the survey.

Prior to the input of nutrients, the $\mathrm{N}: \mathrm{P}$ ratio fluctuated around 50, which could suggest some P-limitation of the community. The nutrient pulse was rich in ammonium, phosphate, and TOC, so apparently supplied enough phosphate to relieve the initial $\mathrm{P}$ constraint. Given the combination of $\mathrm{C}, \mathrm{N}$, and $\mathrm{P}$, we expected a fast bacterial response. However, bacterial numbers barely changed, and neither did other planktonic groups. A few reasons may explain the weak biological response. The nutrient input peak was short-lived, so it might have been advected away before the local system could significantly respond. Caffrey et al. (2007) found very weak biological responses after major nutrient pulses in a small estuary in California, and attributed the lack of response to high flushing rates and ensuing rapid dilution of nutrient peaks. Otherwise, it is possible that the nutrient pulse spurred bacterial growth but that prokaryotes were strongly controlled by grazers, and thus changes in biomass or abundance could not be observed. Bacterial predation by protozoa is a well-studied phenomenon in Mediterranean waters (Thingstad and Rassoulzadegan 1999). In a well-adjusted microbial food web, it is plausible that grazers would rapidly offset any increase in bacterial abundance. This hypothesis would be consistent with the results, since heterotrophic flagellates peaked $1 \mathrm{~d}$ later. Further evidence supporting the latter process was found in a laboratory experiment performed in parallel to the survey with waters from the same sampling location (Romero et al. 2012). When subjected to nutrient enrichments, and notably in the absence of turbulence, a quick burst of autotrophic and heterotrophic picoplankton was systematically observed.

Additional factors could have contributed to the feeble response of the organisms. Among the microphytoplankton, dinoflagellates were the most abundant organisms at the beginning of the spring survey. Dinoflagellates are presumed to have low maximum growth rates (Stolte and
Garcés 2006), so their response to sudden nutrient pulses would be, in any case, limited. Indeed, the group seemed to be declining apace and their collapse was further rushed by the steady increase in turbulence that followed the nutrient peak (Thomas and Gibson 1990; Peters and Marrasé 2000).

In the study area, the planktonic community is dominated by small-sized cells and recycling processes during most of the year. Regardless of the season, urban spills supply high amounts of ammonium and dissolved organic materials to coastal waters (Suárez and Puertas 2005), which benefit the maintenance of active bacterial populations. The continuous anthropogenic influence may therefore constitute an important factor that molds a stable, very active background community in urban coastal systems.

Daily vs. seasonal variability range-The ranges of wind speed and $\mathrm{H}_{\mathrm{s}}$ were similar during both intensive surveys, and moderate with regard to annual variations (Table 3 ). This is consistent with the aims of the study, since we intended to skip large physical disruptions. Conversely, the day-to-day variability of particulate matter, nutrients, and biological variables was on the order of, or slightly below, seasonal variations. In autumn, changes in nutrients were low as compared to annual ranges (on average for all nutrients, the weekly range was $\sim 40 \%$ that of the $7 \mathrm{yr}$ time series), but in spring the weekly variation of phosphate, silicate, and ammonium equaled the range of the multiyear series (Table 3). This was related to the spill on 22 April, and illustrates the magnitude and the transience of occasional nutrient inputs in the area, hardly detectable with monthly or biweekly sampling schemes. With regard to the biological parameters, chlorophyll $>10 \mu \mathrm{m}$ and bacteria showed the greatest variability, with weekly ranges close to the oscillations of the multiyear time series. In summary, fluctuations of nutrients and organisms can occur fast, and although day-to-day changes may be as large as seasonal variations, many of these quick shifts go unnoticed, partly overshadowed by the steadier dynamics of the physical forcing. 
Broader implications of short-term plankton variabilityThe purpose underlying our intensive weekly surveys was to assess, in the context of a coastal area exposed to diverse anthropogenic activities, whether moderate, high-frequency perturbations could be affecting coastal plankton dynamics. We propose that a fine balance between moderate turbulent mixing and nutrient availability pushes our system toward diverse trophic pathways. Roughly, the timing (match or mismatch) of physicochemical perturbations, as well as the relative composition of nutrient pulses, promoted two distinct biological responses: sudden nutrient fluxes uncoupled from turbulent motion tended to favor bacteria and heterotrophic flagellates, whereas their concurrence with some water column mixing shaped a favorable scenario for large autotrophs. This general picture does not differ from longstanding ecological conceptual frameworks (Margalef 1978; Longhurst 2007), but whereas these refer to seasonal biological shifts, we have found equivalent transitions nested within short-term (hours to days) variability. Most probably, the matched forcing of mixing and nutrient load may also explain short-term plankton variability in open-ocean conditions, although this is difficult to test in the open sea due to sampling constraints.

Our results characterize scenarios of short-term variability in a highly anthropic coastal system, and frame the magnitude of such variability with regard to seasonal fluctuations. A good knowledge of seasonal characteristics is an essential first step to understand the basic functioning of most systems, because seasonal shifts set up a predictable cyclic background on which many other variations superimpose. Monitoring schemes are often established on a biweekly or monthly basis (Ribera d'Alcalà et al. 2004; Cloern and Jassby 2008). Such timescales provide a good description of annual cycles, but fail to capture the quick dynamics of coastal areas. Transient events can not only deviate the system from expected seasonal patterns, but they can also fuel a background community that attenuates them. Real-time or high-resolution surveillance programs that catch short-term dynamics are still expensive and not always feasible, but daily samplings should be periodically, say, once per season, carried out in coastal waters affected by a multitude of forcing factors including urban activities in order to assess the importance, and set up limits, on their short-term variability. Accurate meteooceanographic information is currently available that allows anticipation of forcing events and thus facilitates the arrangement of sampling efforts. High-frequency surveys may ultimately provide better clues to which environmental factors are responsible for apparently unpredictable variations in many coastal systems.

\section{Acknowledgments}

We are grateful to A. Sabata, M. Segura-Noguera, E. Laguillo, and C. Romera-Castillo for their kind help during the surveys. We thank L. Arin, who sized and counted microphytoplankton samples, and V. Pérez for her technical assistance with chemical analyses. C. Marrasé provided some insightful comments on the manuscript and we acknowledge M. Estrada for her kind assistance with the principal component analyses. The authors are indebted to James J. Leichter, the Editor, and two anonymous reviewers for their valuable suggestions and comments. E.R. was supported by the Departament d'Educació i Universitats de la
Generalitat de Catalunya and the European Social Fund. Ò.G had a Spanish I3P fellowship funded by the Consejo Superior de Investigaciones Cientificas. This study was funded by the Spanish projects Multiscale approach to the variability of turbulence and its effect on the dynamics of coastal ecosystems (VARITEC, CTM2004-04442-C02), Proyecto Intramural Especial (PIE, 200830 |101 CSIC), Structure of organic matter in the ocean (STORM, CTM2009-09352) and Aerosol deposition and ocean plankton dynamics (ADEPT, CTM2011-23458).

\section{References}

[ACA] Catalan Water Agency. 2005. Caracterització de masses d'aigua i anàlisi del risc d'incompliment dels objectius de la directiva marc de l'aigua (2000/60/CE) a Catalunya. Departament de Medi Ambient i Habitatge, Generalitat de Catalunya. [Characterization of the water masses and assessment of the risk of non-compliance with the targets of the Water Framework Directive (2000/60/CE) in Catalonia.]

Alpine, A. E., And J. E. Cloern. 1988. Phytoplankton growthrates in a light-limited environment, San Francisco Bay. Mar. Ecol. Prog. Ser. 44: 167-173, doi:10.3354/meps044167

Álvarez-Salgado, X. A., M. D. Doval, A. V. Borges, I. Joint, M. Frankignoulle, E. M. S. Woodward, and F. G. Figueiras. 2001. Off-shelf fluxes of labile materials by an upwelling filament in the NW Iberian Upwelling System. Prog. Oceanogr. 51: 321-337, doi:10.1016/S0079-6611(01)00073-8

BJøRnSEN, P. K. 1986. Automatic determination of bacterioplankton biomass by image analysis. Appl. Environ. Microbiol. 51: 1199-1204.

Caffrey, J. M., T. P. Chapin, H. W. Jannasch, and J. C. Haskins. 2007. High nutrient pulses, tidal mixing and biological response in a small California estuary: Variability in nutrient concentrations from decadal to hourly time scales. Estuar. Coast. Shelf Sci. 71: 368-380, doi:10.1016/j.ecss.2006.08.015

Cloern, J. E. 1991. Tidal stirring and phytoplankton bloom dynamics in an estuary. J. Mar. Res. 49: 203-221, doi:10.1357/ 002224091784968611

, AND A. D. JASSBy. 2008. Complex seasonal patterns of primary producers at the land-sea interface. Ecol. Lett. 11: 1294-1303, doi:10.1111/j.1461-0248.2008.01244.x

Collos, Y. 1986. Time-lag algal growth dynamics-biological constraints on primary production in aquatic environments. Mar. Ecol. Prog. Ser. 33: 193-206, doi:10.3354/meps033193

Delgado, M., M. Latasa, And M. Estrada. 1992. Variability in the size-fractionated distribution of the phytoplankton across the Catalan Front of the northwest Mediterranean. J. Plankton Res. 14: 753-771, doi:10.1093/plankt/14.5.753

Eppley, R. W., J. N. Rogers, And J. J. McCArthy. 1969. Halfsaturation constants for uptake of nitrate and ammonium by marine phytoplankton. Limnol. Oceanogr. 14: 912-920, doi:10.4319/1o.1969.14.6.0912

Estrada, M., M. Alcaraz, and C. Marrasé. 1987. Effects of turbulence on the composition of phytoplankton assemblages in marine microcosms. Mar. Ecol. Prog. Ser. 38: 267-281, doi:10.3354/meps038267

Font, J., J. Salat, and J. Tintoré. 1988. Permanent features of the circulation in the Catalan Sea. Oceanol. Acta 9: 51-57.

Franks, P. J. S., ANd C. S. Chen. 1996. Plankton production in tidal fronts: A model of Georges Bank in summer. J. Mar. Res. 54: 631-651, doi:10.1357/0022240963213718

Gasol, J. M., and P. A. Del Giorgio. 2000. Using flow cytometry for counting natural planktonic bacteria and understanding the structure of planktonic bacterial communities. Sci. Mar. 64: 197-224, doi:10.3989/scimar.2000.64n2197 
Grémare, A., AND others. 2003. The effects of a strong winter storm on physical and biological variables at a shelf site in the Mediterranean. Oceanol. Acta 26: 407-419, doi:10.1016/ S0399-1784(03)00029-X

Guadayol, Ò., C. Marrasé, F. Peters, E. Berdalet, C. Roldán, AND A. SABAta. 2009a. Responses of coastal osmotrophic planktonic communities to simulated events of turbulence and nutrient load throughout a year. J. Plankton Res. 31: 583-600, doi:10.1093/plankt/fbp019

— AND OTHERS. 2009b. Episodic meteorological and nutrientload events as drivers of coastal planktonic ecosystem dynamics: A time-series analysis. Mar. Ecol. Prog. Ser. 381: 139-155, doi:10.3354/meps07939

Guerzoni, S., AND OTHERs. 1999. The role of atmospheric deposition in the biogeochemistry of the Mediterranean Sea. Prog. Oceanogr. 44: 147-190, doi:10.1016/S0079-6611(99)00024-5

Hammer, Ø., D. A. T. Harper, and P. D. Ryan. 2001. PAST: Paleontological Statistics software package for education and data analysis. Palaeontol. Electron. 4: 1-9.

Hansen, H. P., and F. KorolefF. 1999. Determination of nutrients, p. 161-228. In K. Grasshoff, K. Kremling, and M. Ehrhardt [eds.], Methods of seawater analysis. WileyVerlag Chemie Weinheim.

Huisman, J., M. Arrayas, U. Ebert, and B. Sommeijer. 2002. How do sinking phytoplankton species manage to persist? Am. Nat. 159: 245-254, doi:10.1086/338511

Jolliffe, I. T. 1986. Principal component analysis. Springer-Verlag.

Karp-Boss, L., E. Boss, and P. A. Jumars. 1996. Nutrient fluxes to planktonic osmotrophs in the presence of fluid motion. Oceanogr. Mar. Biol. 34: 71-107.

Kiørboe, T. 1993. Turbulence, phytoplankton cell-size, and the structure of pelagic food webs. Adv. Mar. Biol. 29: 1-72, doi:10.1016/S0065-2881(08)60129-7

Lazier, J. R. N., And K. H. Mann. 1989. Turbulence and the diffusive layers around small organisms. Deep-Sea Res. 36: 1721-1733, doi:10.1016/0198-0149(89)90068-X

Liquete, C., And others. 2007. Long-term development and current status of the Barcelona continental shelf: A source-tosink approach. Cont. Shelf Res. 27: 1779-1800, doi:10.1016/ j.csr.2007.02.007

Longhurst, A. 2007. Ecological geography of the sea, 2nd ed. Academic Press.

Lucea, A., C. M. Duarte, S. Agustí, and H. Kennedy. 2005. Nutrient dynamics and ecosystem metabolism in the Bay of Blanes (NW Mediterranean). Biogeochemistry 73: 303-323, doi:10.1007/s10533-004-0059-4

Margalef, R. 1978. Life-forms of phytoplankton as survival alternatives in an unstable environment. Oceanol. Acta 1: 493-509.

- M. Estrada, And D. Blasco. 1979. Functional morphology of organisms involved in red tides, as adapted to decaying turbulence, p. 89-94. In D. L. Taylor and H. H. Seliger [eds.], Toxic dinoflagellate blooms. Elsevier.

Martínez Albaladejo, A. 1996. Brises a la costa catalana. Mètode d'estudi i exemple. Terra. Rev. Catalana Geogr. Cartogr. Cienc. Terra 10: 27-32. [Breeze regime of the Catalan coast. Methods of study and example.]

Mercado, J. M., T. Ramírez, D. Cortés, M. Sebastián, E. Liger, And B. Bautista. 2008. Partitioning the effects of changes in nitrate availability and phytoplankton community structure on relative nitrate uptake. Mar. Ecol. Prog. Ser. 359: 51-68, doi: $10.3354 /$ meps07417

Nieto-Cid, M., X. A. Álvarez-Salgado, J. Gago, and F. F. PÉREZ. 2005. DOM fluorescence, a tracer for biogeochemical processes in a coastal upwelling system (NW Iberian Peninsula). Mar. Ecol. Prog. Ser. 297: 33-50, doi:10.3354/meps297033
ÖRnólfsdóttir, E. B., S. E. Lumsden, And J. L. Pinckney. 2004. Phytoplankton community growth-rate response to nutrient pulses in a shallow turbid estuary, Galveston Bay, Texas. J. Plankton Res. 26: 325-339, doi:10.1093/plankt/fbh035

Pannard, A., M. Bormans, and Y. Lagadeuc. 2008a. Phytoplankton species turnover controlled by physical forcing at different time scales. Can. J. Fish. Aquat. Sci. 65: 47-60, doi:10.1139/f07-149

, P. Claquin, C. Klein, B. Le Roy, and B. Veron. 2008 b. Short-term variability of the phytoplankton community in coastal ecosystem in response to physical and chemical conditions' changes. Estuar. Coast. Shelf Sci. 80: 212-224, doi:10.1016/j.ecss.2008.08.008

Peters, F., L. Arin, C. Marrasé, E. Berdalet, and M. M. Sala. 2006. Effects of small-scale turbulence on the growth of two diatoms of different size in a phosphorus-limited medium. J. Mar. Syst. 61: 134-148, doi:10.1016/j.jmarsys.2005.11.012

- AND C. MARRASÉ. 2000. Effects of turbulence on plankton: An overview of experimental evidence and some theoretical considerations. Mar. Ecol. Prog. Ser. 205: 291-306, doi:10.3354/meps205291

Pinckney, J. L., H. W. Paerl, and M. B. Harrington. 1999. Responses of the phytoplankton community growth rate to nutrient pulses in variable estuarine environments. J. Phycol. 35: 1455-1463, doi:10.1046/j.1529-8817.1999.3561455.x

Porter, E. T., R. P. Mason, And L. P. SANFord. 2010. Effect of tidal resuspension on benthic-pelagic coupling in an experimental ecosystem study. Mar. Ecol. Prog. Ser. 413: 33-53, doi:10.3354/meps08709

Porter, K. G., and Y. S. Feig. 1980. The use of Dapi for identifying and counting aquatic microflora. Limnol. Oceanogr. 25: 943-948, doi:10.4319/lo.1980.25.5.0943

Ribera D'Alcalà, M., AND Others. 2004. Seasonal patterns in plankton communities in a pluriannual time series at a coastal Mediterranean site (Gulf of Naples): An attempt to discern recurrences and trends. Sci. Mar. 68: 65-83, doi:10.3989/ scimar.2004.68s 165

Riegman, R., I. A. Flameling, and A. A. M. Noordeloos. 1998. Size-fractionated uptake of ammonium, nitrate and urea and phytoplankton growth in the North Sea during spring 1994. Mar. Ecol. Prog. Ser. 173: 85-94, doi:10.3354/meps 173085

, AND A. A. M. Noordeloos. 1998. Size-fractionated uptake of nitrogenous nutrients and carbon by phytoplankton in the North Sea during summer 1994. Mar. Ecol. Prog. Ser. 173: 95-106, doi:10.3354/meps173095

Roelke, D. L., P. M. Eldridge, And L. A. Cifuentes. 1999. A model of phytoplankton competition for limiting and nonlimiting nutrients: Implications for development of estuarine and nearshore management schemes. Estuaries 22: 92-104, doi: $10.2307 / 1352930$

Romero, E. 2010. Sources of plankton variability in an urbanized coastal ecosystem. Ph.D. thesis. Universitat Politècnica de Catalunya, Barcelona.

- F. Peters, and C. Marrasé. 2012. Dynamic forcing of coastal plankton by nutrient imbalances and match-mismatch between nutrients and turbulence. Mar. Ecol. Prog. Ser. 464: 69-87, doi:10.3354/meps09846

Sanz, M. J., A. Carratalá, C. Gimeno, and M. M. Millán. 2002. Atmospheric nitrogen deposition on the east coast of Spain: Relevance of dry deposition in semi-arid Mediterranean regions. Environ. Pollut. 118: 259-272, doi:10.1016/ S0269-7491(01)00318-9

SmetaceK, V. S. 1985. Role of sinking in diatom life-history cycles: Ecological, evolutionary and geological significance. Mar. Biol. 84: 239-251, doi:10.1007/BF00392493 
Spatharis, S., G. Tsirtsis, D. B. Danielidis, T. D. Chi, and D. Mouillot. 2007. Effects of pulsed nutrient inputs on phytoplankton assemblage structure and blooms in an enclosed coastal area. Estuar. Coast. Shelf Sci. 73: 807-815, doi:10.1016/j.ecss.2007.03.016

Stolte, W., AND E. Garcés. 2006. Ecological aspects of harmful algal in situ population growth rates. Ecol. Harmful Algae 189: 139-152, doi:10.1007/978-3-540-32210-8_11

, T. Mccollin, A. A. M. Noordeloos, and R. Riegman. 1994. Effect of nitrogen-source on the size distribution within marine-phytoplankton populations. J. Exp. Mar. Biol. Ecol. 184: 83-97, doi:10.1016/0022-0981(94)90167-8

SuÁrez, J., and J. Puertas. 2005. Determination of COD, BOD, and suspended solids loads during combined sewer overflow (CSO) events in some combined catchments in Spain. Ecol. Eng. 24: 201-219, doi:10.1016/j.ecoleng.2004. 11.005

Thingstad, T. F., and F. Rassoulzadegan. 1999. Conceptual models for the biogeochemical role of the photic zone microbial food web, with particular reference to the Mediterranean Sea. Prog. Oceanogr. 44: 271-286, doi:10.1016/S0079-6611 (99)00029-4
Thomas, W. H., And C. H. Gibson. 1990. Quantified small-scale turbulence inhibits a red tide dinoflagellate, Gonyaulax polyedra Stein. Deep-Sea Res. 37: 1583-1593, doi:10.1016/ 0198-0149(90)90063-2

UteRmÖHL, H. 1958. Zur Vervollkommnung der quantitativen Phytoplankton-Methodik. Mitt. Int. Ver. Limnol. 9: 1-38. [Toward the improvement of the quantitative methods for phytoplankton studies.]

Verity, P. G., C. Y. Robertson, C. R. Tronzo, M. G. Andrews, J. R. Nelson, and M. E. Sieracki. 1992. Relationships between cell-volume and the carbon and nitrogen-content of marine photosynthetic nanoplankton. Limnol. Oceanogr. 37: 1434-1446, doi:10.4319/1o.1992.37.7.1434

Yentsch, C. S., And D. W. Menzel. 1963. A method for the determination of phytoplankton chlorophyll and phaeophytin by fluorescence. Deep-Sea Res. 10: 221-231.

Associate editor: James J. Leichter

Received: 06 August 2012 Accepted: 28 January 2013 Amended: 08 February 2013 